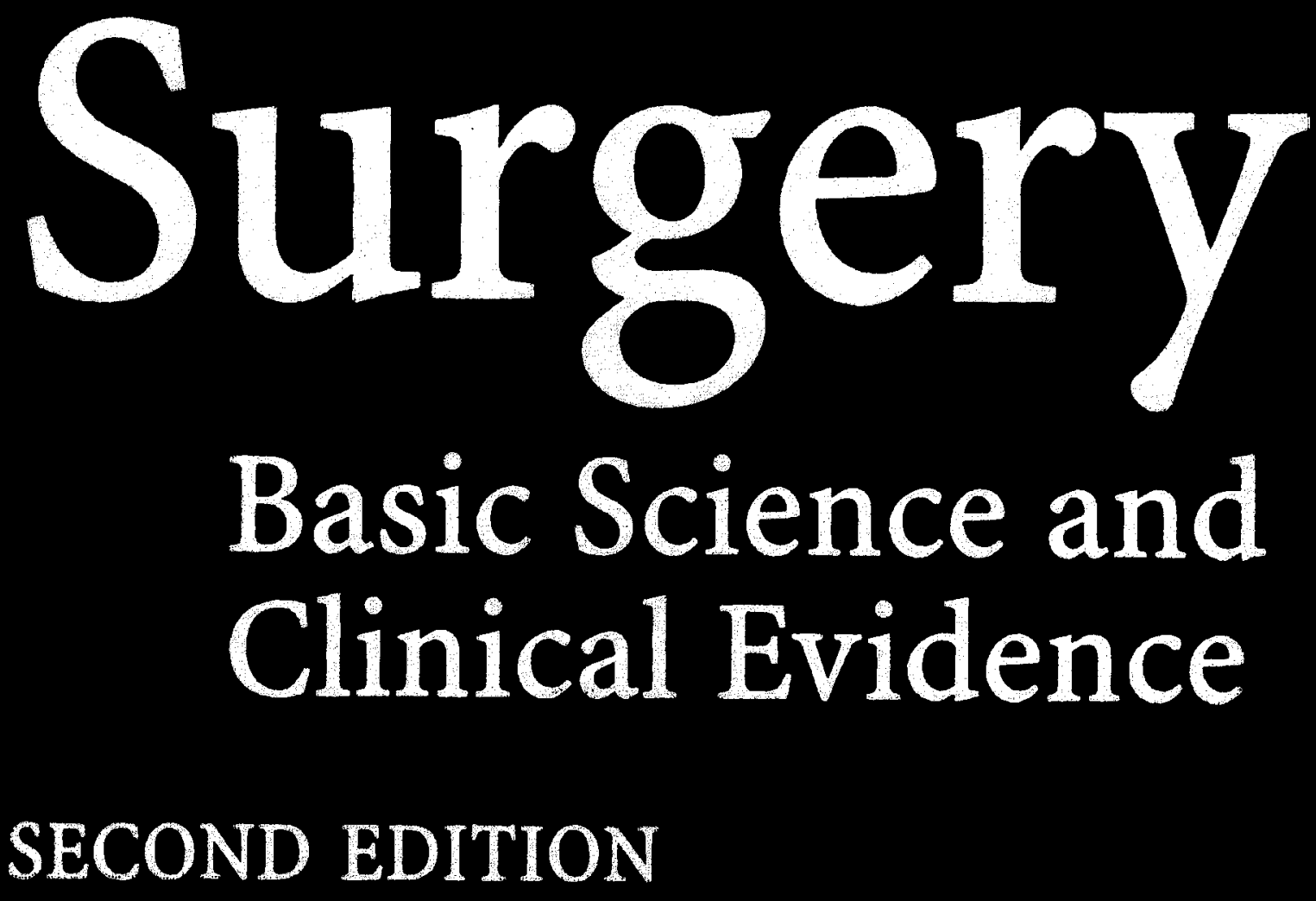




\section{Surgery \\ Basic Science and Clinical Evidence}

Second Edition

Edited by

Jeffrey A. Norton, MD, FACS

Robert L. and Mary Ellenburg Professor, Department of Surgery; Chief, Divisions of Surgical Oncology and General Surgery, Department of Surgery, Stanford University Medical Center, Stanford, Califomia

Philip S. Barie, MD, MBA, FCCM, FACS

Professor, Departments of Surgery and Public Health; Chief, Division of Critical Care and Trauma, NewYork-Presbyterian Hospital/Weill Comell Medical College, New York, New York

R. Randal Bollinger, $\mathrm{MD}, \mathrm{PhD}$, FACS

Professor, Departments of Surgery and Immunology, Duke University Medical Center, Durham, North Carolina

Alfred E. Chang, MD, FACS

Chief, Division of Surgical Oncology, Hugh Cabot Professor of Surgery, Department of Surgery, University of Michigan, Comprehensive Cancer Center, Ann Arbor, Michigan

Stephen F. Lowry, MD, MBA, FACS

Professor and Chairman, Department of Surgery, University of Medicine and Dentistry of New Jersey, Robert Wood Johnson Medical School, New Brunswick, New Jersey

Sean J. Mulvihill, MD, FACS

Professor and Chair, Department of Surgery; Senior Director of Clinical Affairs, Huntsman Cancer Institute; The University of Utah, Salt Lake City, Utah

Harvey I. Pass, MD, FACS

Professor, Departments of Cardiothoracic Surgery and Surgery, New York University Medical Center, New York, New York

Robert W. Thompson, MD, FACS

Professor of Surgery (Section of Vascular Surgery), Radiology, and Cell Biology and Physiology; Vice-Chairman for Research, Department of Surgery, Washington University School of Medicine, St. Louis, Missouri

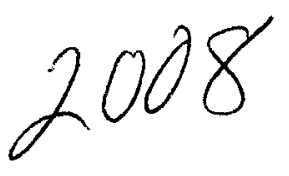

\section{Springer}




\title{
History of Clinical Transplantation
}

\author{
Thomas E. Starzl
}

Prehistory: Before Immunosuppression . . . . . . . . . 1682

The Concept of Immunosuppression .............. 1684

The Maturation of Transplantation ............... 1689

The Ripple Effect ......................... 1691

Immunological Screening ..................... 1692
Allograft Acceptance Versus Acquired Tolerance . . . . . 1693

Conclusion . . . . . . . . . . . . . . . . . . . . . . . . . . 1697

Epilogue . . . . . . . . . . . . . . . . . . . . . . . . . . . . . 1697

References.................................1697
$\mathrm{H}$ ow transplantation came to be a clinical discipline can be pieced together by perusing two volumes of reminiscences collected by Paul I. Terasaki in 19911992 from many of the persons who were directly involved. One volume was devoted to the discovery of the major histocompatibility complex (MHC), with particular reference to the human leukocyte antigens (HLAs) that are widely used today for tissue matching. ${ }^{1}$ The other focused on milestones in the development of clinical transplantation. ${ }^{2}$ All the contributions described in both volumes can be traced back in one way or other to the demonstration in the mid-1940s by Peter Brian Medawar that the rejection of allografts is an immunological phenomenon. ${ }^{3,4}$

Ten years later (1953), Billingham, Brent, and Medawar ${ }^{5}$ showed that tolerance to skin allografts could be induced by inoculating fetal or prenatal mice with immunocompetent spleen cells from adult donors. Because of their immunological immaturity, the recipients were incapable of rejecting the spleen cells with progeny that survived indefinitely. Specific nonresponsiveness to donor strain tissues was retained as the recipient animals grew to adult life, while normal reactivity evolved to third-party grafts and other kinds of antigens.

This was not the first demonstration that tolerance could be deliberately produced. Analogous to the neonatal transplant model, Traub ${ }^{6}$ showed in 1936 that the lymphocytic choriomeningitis virus (LCMV) persisted after transplacental infection of the embryo from the mother or by injection into newborn mice. However, when the mice were infected as adults, the vinus was eliminated immunologically. Similar observations had been made in experimental tumor models. Murphy reported in 1912 on the outgrowth of Rous chicken sarcoma cells on the chorioallantoic membranes of duck or pigeon egg embryos, which could be reversed by inoculation of adult chicken lymphoid cells, ${ }^{8}$ whereas sarcoma implantation into adults was not possible.

The observations of Murphy and Traub did not influence the early development of transplantation. Instead, the impetus and rationale for the experiments of Billingham, Brent, and inated with Owen, ${ }^{11}$ who demonstrated that freemartin cattle (the calf equivalent of human fraternal [dizygotic] twins) became permanent hematopoietic chimeras if fusion of their placentas existed in utero, allowing fetal cross-circulation (Fig. 79.1); such animals permanently accept each other's skin. ${ }^{12}$ Burnet and Fenner ${ }^{13}$ predicted that this natural chimerism and tolerance to other donor tissues and organs could be induced by the kind of experiments successfully performed by Billingham, Brent, and Medawar. However, Billingham and Brent ${ }^{14,15}$ soon leamed that, in mice, parallel with similar observations by Simonsen ${ }^{16}$ in chickens, the penalty for infusion of immunocompetent hematopoietic cells was graftversus-host disease (GVHD) unless there was a close genetic relationship (i.e., histocompatibility) between the donor and recipient.

This discovery was the beginning of modern transplantation immunology, an extensive history of which has been written by Brent, ${ }^{17}$ one of its principal architects. Each celland organ-defined branch of transplantation also has had its historians, who have described the stages through which specific kinds of procedures moved to the bedside from experimental laboratories or in some cases directly. The culminating clinical events can be capsulized with a list of the first successful allotransplantation, in humans, of the kidney, ${ }^{18}$ liver, ${ }^{19}$ heart, ${ }^{20,21}$ lung, ${ }^{22}$ pancreas, ${ }^{23}$ intestine, ${ }^{24}$ multiple abdominal viscera, ${ }^{25}$ and bone marrow. ${ }^{26-29}$

Although such milestones and dozens of lesser ones are important, the emphasis in this account is on developments that were applicable to all varieties of allografts and responsible for major transitions in transplantation ideology. It will become apparent as the layers of history are peeled away that there were only two seminal turning points in the evolution of clinical transplantation. One was the induction of chimerism-associated neonatal tolerance by Billingham, Brent, and Medawar in 1953. The second was the demonstration in 1962-1963 that organ allografts could self-induce tolerance with the aid of immunosuppression. ${ }^{30}$ All subsequent developments in organ transplantation depended on exploitation of this principle, using variations of the drug strategy that had 


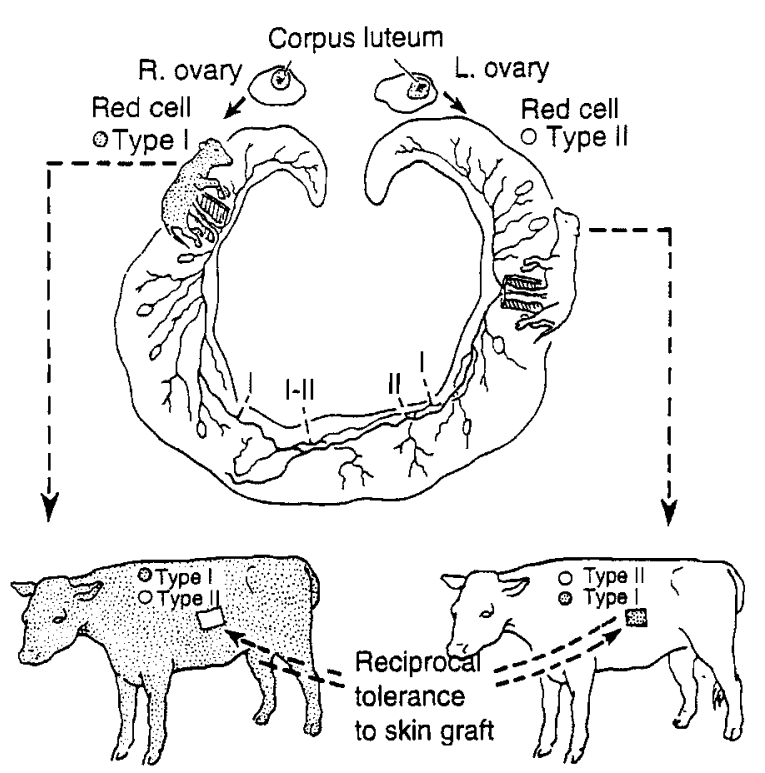

FIGURE 79.1. The chimerism in freemartin (fraternal twins) described by Owen. ${ }^{11}$ Cross-tolerance to formed blood elements followed intrauterine circulatory exchange in dizygotic twins. Mutual tolerance to skin grafts was later proved by Anderson with Medawar et al. ${ }^{12}$ (From Starzl and Butz, ${ }^{146}$ by permission of Surgical Clinics of North America.)

made its discovery possible. Ironically, the downside of the resulting revolution in organ transplantation was the early introduction of a conceptual error that distorted the maturation of transplantation immunology and adversely affected the orderly development of general immunology.

The error, which was not corrected until well into the $1990 \mathrm{~s}^{31-33}$ was the conclusion by consensus that organ allograft acceptance involved different mechanisms compared to the chimerism-dependent ones of neonatal tolerance and its clinical analogue of bone marrow transplantation. Consequently, the vast literature that sprang up in the intervening 30 years admirably documented the progression of improvements in clinical transplantation while failing to explain what was being accomplished ${ }^{34}$ Therefore, the reader may profit by skipping to the last section of this chapter |"Allograft Acceptance Versus Acquired Tolerance") before attempting to understand what went on between 1963 and 1993 and before.

\section{Prehistory: Before Immunosuppression}

An indelible mark on the pages of transplantation history was left with the perfection of techniques for organ revascularization by surgical anastomosis in the laboratories of Alexis Carrel at the beginning of the 20th century. ${ }^{35}$ Aside from the technical contributions, which also provided the foundation for conventional vascular surgery, Carrel recognized that transplanted organ allografts were not permanently accepted, although he did not know why.

Using vascular surgical techniques, animal research in transplantation was most highly focused on the kidney for most of the next half-century. ${ }^{36-38}$ The extrarenal vacuum rapidly was filled between 1958 and 1960 with the development in several laboratories of canine models with which to study all the intra-abdominal ${ }^{39-43}$ and thoracic organs. ${ }^{4-46}$ Although each organ presented specific technical and physiological issues, the core problems of immunosuppression, tissue matching, and allograft preservation eventually were worked out mainly with the kidney and liver and applied to other organs with minor modifications.

\section{Hetero- (Xeno-) transplantation}

The first known attempts at clinical renal transplantation by vascular anastomoses were made between the beginning of the 19th century and 1923 in France, ${ }^{47}$ Germany, ${ }^{48}$ and elsewhere (summarized by Groth $^{49}$ ) using pig, sheep, goat, and subhuman primate donors. None of the kidneys functioned for long, if at all, and the human recipients died a few hours to 9 days later. No further animal-to-human transplantations were tried again until 1963, after immunosuppression was available. $^{50,51}$

\section{Homo- (Allo-)transplantation}

In 1936, Voronoy of Kiev, Russia, reported the transplantation of a kidney from a cadaver donor of $B$ blood type to a recipient of $\mathrm{O}$ blood type ${ }^{52}$ in violation of what have become accepted rules of tissue transfer ${ }^{53,54}$ (Table 79.1). In addition, the allograft was jeopardized by the residual risk of acute mercury poisoning (from a suicide attempt) that caused the recipient's renal failure. A final adverse factor was the 6-h lapse between the donor's death and organ procurement. The allograft did not make any urine during the $48 \mathrm{~h}$ of the patient's posttransplant survival. Although other attempts may have been made by Voronoy, ${ }^{55}$ another 15 years passed before significant kidney transplant activities were resumed in France.

In 1951, Rene Kuss ${ }^{56}$ and Charles Dubost ${ }^{57}$ in Paris and Marceau Servelle in Cretei ${ }^{58}$ carried out a series of renal transplantations with kidneys removed from convict donors immediately after their execution by guillotine. The next year, the French nephrologist Jean Hamburger, in collaboration with the urologist Louis Michon at the Hôpital Necker in Paris, reported the mother-to-son transplantation of a kidney that functioned well for 3 weeks before rejection. ${ }^{59}$ The procedure developed by Kuss and the other French sur-

TABLE 79.1. Direction of Acceptable Organ Transfer When the Donor and Recipient Have Different ABO Red Cell Types.

\begin{tabular}{ll}
\hline $\mathrm{O}$ to non-O & Safe \\
$\mathrm{Rh}-$ to $\mathrm{Rh}+$ & Safe \\
$\mathrm{Rh}+$ to $\mathrm{Rh}-$ & Relatively safe \\
$\mathrm{A}$ to non- $\mathrm{A}$ & Dangerous \\
$\mathrm{B}$ to non- $\mathrm{B}$ & Dangerous \\
$\mathrm{AB}$ to non- $\mathrm{AB}$ & Dangerous \\
\hline
\end{tabular}

For organ transplantation, $O$ is universal donor, and $A B$ is universal recipient. With the transplantation of bone marrow allografts or of lymphoid-rich organ allografts (e.g., intestine or liver), enough antihost isoagglutinins may be produced by the allograft to cause serious or lethal hemolysis in a significant number of cases (humoral GVHD) ${ }^{54}$ Consequently, the nules summarized in this table are fully applicable only with leukocyte-poor organs such as the kidney and heart |see the section, "Allograft Acceptance Versus Acquired Tolerance"

Source: From Starzl $(1964)^{53}$ 
geons and used for this first live donor kidney transplantation has been performed hundreds of thousands of times since then. The operation's relative freedom from chronic morbid ity would soon be demonstrated with the identical /monozy. goticl twin transplantations of Joseph E. Murray and John Merrill and their associates ${ }^{60}$ at the Peter Bent Brigham Hospital in Boston.

The efforts by the French teams were widely known, and visitors flocked to Paris in the early 1950 s to learn firsthand from the experience. One of the observers of the extraperitoneal pelvic operation loften called the Kuss procedure in Europe) was John Merrill, as Hume, Merrill, et al. ${ }^{61}$ described in their account of the first clinical trials at the Peter Bent Brigham Hospital. In Hume's nine Boston cases, however, all but one of the allografts were placed in the recipient thigh, revascularized from the femoral vessels, and provided with urinary drainage by skin ureterostomies.

The exceptional case in the Boston series ${ }^{61}$ was the first one. The donor and recipient operations were performed in Springfield, Massachusetts, on March 30, 1951, by Dr. L.H. Doolittle. The donor kidney was excised because of a carcinoma of the lower ureter and implanted in the vacated renal fossa of the recipient after removal of the native organ. The recipient patient had been under short-term dialysis care at the Brigham, where the first artificial kidney in the United States had been brought from Holland by Wilhelm Kolff and modified by Harvard engineers, as described in detail by Moore. $^{62}$

The next eight operations, in which the allografts were placed in the anterior thigh location, were performed by Hume in Boston between April 23, 1951, and December 3, 1952. The report of the nine cases stands as one of the medical classics of the 20th century, providing an extensive clinical and pathological profile of renal allograft rejection in untreated human recipients. The descriptions complemented the report of Michon and Hamburger of the live donor French case /see earlier ${ }^{59} \mid$ and the pathfinding studies in dogs by the Dane, Morten Simonsen, ${ }^{37}$ and W. James Dempster in England. ${ }^{38}$ It is noteworthy that Hume treated some of his patients with adrenocortical steroids. It was already known from experimental studies that steroid therapy modestly mitigated primary skin graft rejection ${ }^{63-65}$ and even slowed the accelerated rejection of presensitized recipients. ${ }^{66}$

Although compilation of the Boston series postdated the early French efforts (as generously annotated by Hume), the commitment of the Harvard group to transplantation was evident long before the availability of effective immunosuppression. Hume, who moved in 1956 from Boston to the Medical College of Virginia (Richmond), remained a major force in transplantation until his death in the crash of a private plane (of which he was the pilot) near Los Angeles in May 1973. His friend and colleague, John Merrill, who remained in Boston, drowned off the beach of a Caribbean island in 1984

None of the European and American efforts to this time, or all together, would have had any lasting impact on medical practice were it not for what lay ahead. The principal ingredients of organ transplantation-immunosuppression, tissue matching, and organ procurement (and preservation)-were still unknown or undeveloped. The only unequivocal example of clinically significant allograft function through 1954 was provided by one of the nonimmunosuppressed patients of
Hume et al., ${ }^{61}$ whose thigh kidney produced life-supporting urine output for 5 months. Similar claims about function of an allograft transplanted to the orthotopic location ${ }^{67}$ (i.e., as in Doolittle's case ${ }^{61}$ ) or to a nonanatomical site ${ }^{68}$ were con sidered implausible by later critics.

The existence of these cases was public knowledge, but the failure of all the grafts (usually with death of the patients) left very little room for optimism. The perception, if not the reality, of hopelessness was changed at the Peter Bent Brigham Hospital 2 days before Christmas in 1954, when a kidney was removed from a healthy man by the urologist J. Hartwell Harrison and transplanted by Joseph E. Murray to the pelvic location of the donor's uremic identical twin brother. ${ }^{60,69}$ Although no effort was made to preserve the isograft, it func. tioned promptly despite $82 \mathrm{~min}$ of warm ischemia. The recipient lived for nearly 25 years before dying of atherosclerotic coronary artery disease.

According to Merrill et al., ${ }^{60}$ exploitation of genetic identity for whole-organ transplantation had been suggested by the recipient's physician, David C. Miller, at the Public Health Service Hospital, Boston. It already was well known that identical twins did not reject each other's skin grafts. ${ }^{70}$ To ensure identity, reciprocal skin grafting was performed in the Boston twins. Although the identical twin cases attracted worldwide attention, organ transplantation now had reached a dead end. Further progress in the presence of an immunological barrier would require effective immunosuppression. The possibility of meeting this objective could only be regarded as bleak. To understand why, it is necessary to appreciate not only how barren the landscape of immunology was, but also how slowly the preexisting information had been filled in.

A century had passed between the first vaccination procedure in 1796 (Edward Jenner, smallpox) and the confirmation of the immunization principle by Louis Pasteur (with chicken cholera and rabies). The proof obtained by Robert Koch that microorganisms caused anthrax (1876) and subsequently many other infectious diseases stimulated a search for the host-protective mechanisms. This search yielded components of the immune response: antibodies (Emil Adolf von Behring and Shibasaburo Kitasato, 1890); immune cells (Ilya Metchnikoff, 1884); and complement (Jules Bordet, 1895). In addition, Paul Erlich developed the side-chain theory (1890), according to which each cell has a vital center of protein substance and a series of side chains (later known as receptors) to which toxic substances as well as nutrients were absorbed and then assimilated. In 1910, Erlich introduced the first antimicrobial drug, an arsenical compound effective against syphilis, yaws, and several other infections.

Decades passed between the cluster of great contributions at the turn of the 20th century and the proposal by F. McFarlane Burnet that antibodies were produced in each individual only to those antigens to which he or she was exposed. ${ }^{13}$ The lack of major movement between times is evident from a list of Nobel Prizes (Table 79.2). Although 6 of the first 17 Nobel laureates (1901-1919) were honored for work relevant to immunology/transplantation, there was only one further example (Karl Landsteiner, $A B O$ blood groups) among the next 57 (1920-1959). Beginning with Burnet and Medawar, 17 of the 77 laureates since 1960 have been directly responsible for, contributed to, or directly benefited from advances in transplantation (Table 79.2). 
TABLE 79.2. Nobel Prizes Related to Immunology/ Transplantation.

\begin{tabular}{|c|c|c|}
\hline Year & Name & Accomplishment \\
\hline 1901 & Emil Adolf von Behring & Discovery of antibodies \\
\hline 1905 & $\begin{array}{l}\text { Heinrich Hermann Robert } \\
\text { Koch }\end{array}$ & $\begin{array}{l}\text { Cause and effect of } \\
\text { microorganisms and } \\
\text { infection }\end{array}$ \\
\hline \multirow[t]{2}{*}{1908} & Paul Ehrlich & $\begin{array}{l}\text { Side-chain (receptor) concept; } \\
\text { champion of humoral } \\
\text { immunity; antimicrobial } \\
\text { therapy }\end{array}$ \\
\hline & Ilya Metchnikoff & $\begin{array}{l}\text { Champion of cellular } \\
\text { immunity }\end{array}$ \\
\hline 1912 & Alexis Carrel & $\begin{array}{l}\text { Vascular surgery and } \\
\text { transplantation }\end{array}$ \\
\hline 1919 & Jules Bordet & Discovery of complement \\
\hline 1930 & Karl Landsteiner & $\begin{array}{l}\text { Discovered ABO blood group } \\
\text { antigens }\end{array}$ \\
\hline \multirow[t]{2}{*}{1960} & $\begin{array}{l}\text { Sir Frank MacFarlane } \\
\text { Burnet }\end{array}$ & Clonal selection hypothesis \\
\hline & Sir Peter Brian Medawar & $\begin{array}{l}\text { Acquired transplantation } \\
\text { tolerance }\end{array}$ \\
\hline \multirow[t]{2}{*}{1972} & Gerald M. Edelman & $\begin{array}{l}\text { Characterized } \\
\text { immunoglobulins }\end{array}$ \\
\hline & Rodney R. Porter & $\begin{array}{l}\text { Clarified structure of antibody } \\
\text { molecule }\end{array}$ \\
\hline \multirow[t]{3}{*}{1980} & Baruj Benacerrat & $\begin{array}{l}\text { Discovered immune response } \\
\text { genes and collaborated in } \\
\text { discovery of MHC } \\
\text { restriction }\end{array}$ \\
\hline & Jean Dausset & Discovered first HLA antigen \\
\hline & George Davis Snell & $\begin{array}{l}\text { Discovery of major } \\
\text { histocompatibility complex } \\
\text { (MHC) gene in mice }\end{array}$ \\
\hline \multirow[t]{2}{*}{1984} & Niels Kaj Jerne & $\begin{array}{l}\text { Important immunological } \\
\text { hypotheses }\end{array}$ \\
\hline & $\begin{array}{l}\text { Georges J.F. Kohler } \\
\text { Cesar Milstein }\end{array}$ & $\begin{array}{l}\text { Hybridoma technology } \\
\text { Hybridoma technology }\end{array}$ \\
\hline \multirow[t]{2}{*}{1985} & Michael Stuart Brown & $\begin{array}{l}\text { Hepatic control of cholesterol } \\
\text { metabolism (with } \\
\text { Goldstein) }\end{array}$ \\
\hline & Joseph Leonard Goldstein & \\
\hline 1987 & Susumu Tonegawa & $\begin{array}{l}\text { Discovered somatic } \\
\text { recombination of } \\
\text { immunological receptor } \\
\text { genes }\end{array}$ \\
\hline \multirow[t]{2}{*}{1988} & Gertrude Belle Elion & $\begin{array}{l}\text { Codiscovery (with Hitchings) } \\
\text { of 6-mercaptopurine (6-MP) } \\
\text { and azathioprine }\end{array}$ \\
\hline & George Herbert Hitchings & \\
\hline 1990 & $\begin{array}{l}\text { Joseph E. Murray } \\
\text { E. Donnall Thomas }\end{array}$ & $\begin{array}{l}\text { Kidney transplantation } \\
\text { Bone marrow transplantation }\end{array}$ \\
\hline 1996 & Rolf Zinkernagel & $\begin{array}{l}\text { Codiscovered (with Doherty) } \\
\text { the role of MHC in } \\
\text { adaptive immune response } \\
\text { to pathogens }\end{array}$ \\
\hline
\end{tabular}

"Proved with liver transplantation for indication of hypercholesterolemia. ${ }^{24,250}$

In Burnet's original hypothesis of immunity, antibody synthesis was postulated to occur after an antigen locked on to a membrane-bound receptor (a version of the antibody) that was displayed at the surface of an immune cell. After binding the antibody, the cell proliferated, producing a clone that secreted identical antibodies (the clonal selection theory). Nossal subsequently proved that the clone rose from a single cell ("one cell/one antibody") ${ }^{71}$ Although Burnet's hypothesis was not yet complete, it was to become the comerstone of modern immunology.

\section{The Concept of Immunosuppression}

\section{With Recipient Cytoablation}

The transition of tissue and organ transplantation from an exercise in futility to tenuous practicality involved a surprisingly small number of advances that were interspersed with long periods of frustration. After Medawar's demonstration in 1944 that rejection was an immunological event, ${ }^{3,4}$ a logical and inevitable question was, why not protect the organ allograft by weakening the immune system? This idea was tested in rabbits in 1950-1951 with cortisone $e^{63,64}$ and totalbody irradiation (TBI). ${ }^{72}$ Both prolonged skin graft survival for only a few days.

Neither these results nor those reported with cortisone in 1952 by Cannon and Longmire ${ }^{65}$ in a chicken skin graft model, generated much optimism. However, the Cannon-Longmire report contained three observations that, in retrospect, presaged not only the acquired neonatal tolerance produced by Billingham, Brent, and Medawar the following year, but also the most important clinical advances in transplantation of the succeeding decades. First, skin grafts exchanged between 1-day-old chicks of different breeds had a high rate of initial engraftment and a $6 \%$ incidence of permanent take. Second, the window of neonatal opportunity was gone by 4 days. Third, and most important, the percentage of permanent engraftment of neonatally transplanted skin was increased to more than $20 \%$ by a course of cortisone with no increase of mortality.

The significance of the third observation was recognized by Cannon and Longmire, who wrote:

Although the cortisone did not entirely prevent a reaction in the homograft, it did decrease the incidence of reaction. Even more important, the increased incidence of reaction [sic] free grafts appeared to maintain itself after the drug was discontinued. This phenomenon is one which up to the present time has not been found in homograft experiments on mammals and humans.

Despite a 1957 confirmatory follow-up study, ${ }^{73}$ the neglected Cannon-Longmire article faded quickly from the collective memory of both basic scientists and clinicians. In contrast, the 1953 achievement of acquired neonatal tolerance by Billingham, Brent, and Medawar ${ }^{5,9}$ ignited interest in transplantation as never before. Two years later, Main and Prehn ${ }^{74}$ attempted to simulate in adult mice the environment that allowed the acquisition of neonatal tolerance. The three steps were first to cripple the immune system with supralethal TBI; next to replace it with allogeneic bone marrow (producing a hematolymphopoietic chimera); and finally to engraft skin from the same inbred strain as the donor of the bone marrow.

The experiments were successful, ${ }^{74}$ but as in the neonatal tolerance model, lethal GVHD could be avoided only when there were "weak" histocompatibility barriers. ${ }^{75}$ Applying the chimerism strategy for kidney transplantation in beagle dogs in Cooperstown, New York, Mannick et al. ${ }^{76}$ reported good renal allograft function in a supralethally irradiated recipient that also was given donor bone marrow and was a hemato- 
lymphopoietic chimera; the animal lived for 73 days before dying of pneumonia. Because it was demonstrated later that this kind of outcome depended on the identity of the dog lymphocyte antigens (DLAs), ${ }^{77,78}$ an accidental DLA match was suspected in retrospect to have been present in Mannick's experiment. Efforts by Hume et al. ${ }^{79}$ and subsequently by Rapaport and coworkers ${ }^{80}$ and others to broaden the range of acceptable histoincompatibility inevitably led to lethal GVHD, rejection, or both.

\section{Bone Marrow Transplantation}

With the impasse, workers in bone marrow and whole-organ transplantation took separate pathways. Bone marrow transplantation was dependent a priori on the classic chimerismassociated acquired tolerance induction defined at the outset by Billingham, Brent, and Medawar in the neonatal model. In spite of the fact that only highly histocompatible donors could be used, clinical success with bone marrow engraftment was achieved in 1963 by Mathe et al. in Paris, ${ }^{26}$ whose patient lived for 2 years with chronic GVHD before committing suicide.

Five years later, Gatti et al. in Minneapolis ${ }^{28}$ and Bach et al. at the University of Wisconsin ${ }^{27}$ each transplanted bone marrow to recipients who are well today. The lifetime efforts of Thomas, ${ }^{29}$ van Bekkum, ${ }^{81}$ and others fueled the maturation of bone marrow transplantation into accepted clinical therapy for numerous hematological diseases (including malignancies), acquired immunodeficiency disorders, mesenchymalbased inborn errors of metabolism, and an assortment of other indications.

Bone marrow transplantation was an intellectual triumph. Its development could be traced in a straight line back to the experiments of Main and Prehn ${ }^{74}$ and before that to the acquired neonatal tolerance of Billingham, Brent, and Medawar ${ }^{5,9}$ and the natural tolerance of Owens' freemartin cattle. ${ }^{11}$

\section{Whole-Organ Transplantation}

In contrast, clinical organ transplantation, which preceded bone marrow transplantation by a decade, appeared to be disconnected from a rational base when it was concluded that organ engraftment seemingly was independent of chimerism. An extension of the Main-Prehn strategy (i.e., lethal TBI followed by bone marrow and kidney allografts as in Mannick's dog) was used by Murray et al. ${ }^{82}$ in only two cases, both in 1958. The next 10 kidney recipients in Boston were conditioned with sublethal TBI without bone marrow. ${ }^{18,82,83}$ Of the 12 irradiated patients, 11 died after 0 to 28 days.

The survivor (who was not given bone marrow) had adequate renal function from the time his fraternal twin brother's kidney was transplanted on January 24,1959 , until he died in July 1979 (Table 79.3). With this historical accomplishment, the genetic barrier to organ transplantation had been definitively breached for the first time in any species. ${ }^{18}$ Five months later, Hamburger et al. ${ }^{84}$ added a second fraternal twin transplantation using the same treatment (Table 79.3). This second recipient had good renal function until his death 26 years later from carcinoma of the urinary bladder.

In these two dizygotic twin cases, it was conceivable that the donor and recipient placentas had fused during gestation, analogous to Owen's freemartin cattle (see Fig. 79.1). This suspicion was put to rest at the Paris centers of Jean Hamburger $^{85}$ and Rene Kuss ${ }^{86}$ by four more examples during 1960 1962 of survival of 1 year or more. In Kuss' two cases, the donors were not related (see Table 79.3). During the critical period from January 1959 through the spring of 1962, the cumulative French experience was the principal (and perhaps the onlyl justification to continue clinical trials in kidney transplantation.

The experience from Boston and Paris summarized in Table 79.3 showed that bone marrow infusion was not a necessary condition for prolonged survival of kidney allografts and ostensibly eliminated the requirement of chimerism. The stage was set for drug therapy. In fact, both Hamburger and Kuss mentioned the use of adrenal cortical steroids as an adjunct to TBI (Table 79.3), but neither the dose nor the indication for the steroids was described. In addition, Kuss ${ }^{86} \mathrm{sec}-$ ondarily administered 6-mercaptopurine (6-MP) to one of his cytoablated patients as early as August 1960 "on the basis of the recent results of the experimental studies conducted by Calne ${ }^{\prime \prime 87}$ (see next section). Calne had made an invited visit to the Paris center a few months earlier (Rene Kuss and Roy Calne, personal communication).

\begin{tabular}{|c|c|c|c|c|c|}
\hline Case & City & References & Date & Donor & Survival (months) \\
\hline 1 & Boston & $18,82,83$ & January 24, 1959 & Fraternal twin & $>50$ \\
\hline 2 & Paris & 84,85 & June 29,1959 & Fraternal twin & $>5$ \\
\hline 3 & Paris & 86 & June 22,1960 & Unrelated $^{c}$ & 18 (died) \\
\hline 4 & Paris & 85 & December 19, 1960 & Mother & 12 (died) \\
\hline 5 & Paris & 86 & March 12, 1961 & Unrelated $^{c}$ & 18 (died) \\
\hline 6 & Paris & 18 & February 12,1962 & Cousin $^{\mathrm{C}}$ & $>13$ \\
\hline 7 & Boston & 83,105 & April 5, 1962 & Unrelated & 10 \\
\hline
\end{tabular}

${ }^{2}$ Boston: J.E. Murray (patients 1,7 ); Paris: J. Hamburger (patients 2, 4, 6), R. Kuss (patients 3, 5).

the kidneys in patients 1,2 , and 6 functioned for $20.5,25$, and 15 years, respectively. Patient 7 rejected his graft after 17 months and died after return to dialysis.

${ }^{c}$ Adjunct steroid therapy. 
Some authorities have considered irradiation-induced and drug-induced graft acceptance to be different phenomena. $49,83,88$ More recentiy, it has become obvious that the variable degree of graft acceptance achieved with sublethal TBI between January 1959 and February 1962 was fundamentally the same as that seen in tens of thousands of drug-treated humans following transplantation of various whole organs (see the section "Allograft Acceptance Versus Acquired Tolerance").

\section{With Drug Immunosuppression}

After it was learned that TBI alone could result in prolongation of kidney allografts, it was logical to focus the search for immunosuppressive drugs on myelotoxic agents that mimicked irradiation. In September 1960, Willard Goodwin of Los Angeles produced severe bone marrow depression with methotrexate and cyclophosphamide in a young female recipient of her mother's kidney. The patient subsequently developed several rejections that were associated with bone marrow recovery. They were temporarily reversed with prednisone several times during the 143 days of survival. It was the first example of protracted human kidney allograft function with drug treatment alone. ${ }^{39}$ However, the case was not reported until 1963.

Kidney transplant surgeons were quick to realize that bone marrow depression should be avoided, not deliberately imposed, following the demonstration by Schwartz and Dameshek ${ }^{90}$ that 6-mercaptopurine (6-MP) in a nontransplant rabbit model was immunosuppressive in submyelotoxic doses. Within a few months after their seminal discovery, Schwartz and Dameshek ${ }^{91}$ and Meeker $^{92}$ (working with Condie, Weiner, Varco, and Goodl showed that 6-MP caused a dose-related delay of skin graft rejection in rabbits. Aware of these results but independent of each other, Calne ${ }^{93}$ in London and Zukoski, Lee, and Hume ${ }^{94}$ in Richmond, Virginia, demonstrated the same thing in the canine kidney transplant model. In June 1960, Calne moved from the Royal Free Hospital to join Murray at the Peter Bent Brigham Hospital in Boston in further preclinical studies of 6-MP and its analogue, azathioprine. ${ }^{83,95-97}$

The two drugs had been developed originally by Gertrude Elion and George Hitchings as antileukemia agents. ${ }^{98}$ Their possible use in transplantation was greeted at first with feverish enthusiasm because it was generally conceded that recipient cytoablation would permit success in only occasional cases of human renal transplantation. Although approximately $95 \%$ of the mongrel canine kidney recipients treated with 6-MP or azathioprine died in fewer than 100 days from either rejection or infection, occasional examples were recorded of long-term or seemingly permanent allograft acceptance ${ }^{99-102}$ following discontinuance of a 4-to 12-month course of immunosuppression. The number of these animals was discouragingly small, but it was an accomplishment never remotely approached using TBI, with or without adjunct bone marrow. Survival of Mannick's single cytoablated animal for 73 days after combined bone marrow and kidney transplantation had been the previous high-water mark in dogs (see earlier ${ }^{76}$.

The survival of some of Calne's animals beyond 6 months led to the decision at the Brigham to begin clinical trials with chemical immunosuppression. However, the poor therapeu- tic margin of 6-MP and azathioprine when used alone in dogs was recognized. Calne and Murray also were forewarned by an earlier clinical experience of Hopewell, Calne, and Beswick et al., ${ }^{103}$ which was not published until 1964, in which 6-MP had been used to treat three kidney recipients (including one with a live donor) in 1959-1960; all three recipients had died.

Consequently, the canine studies of 6-MP and azathioprine in Boston were highly focused on finding more effective drug combinations. ${ }^{83,95,97,104}$ Although adrenocortical steroids were tested, they did not appear to potentiate the value of azathioprine, ${ }^{95,97}$ prompting Murray in his clinical trial to opt for adjunct cytotoxic agents such as azaserine and actinomycin $C^{83}$ Only 1 of the first 10 kidney recipients treated with either 6-MP ( $\mathrm{n}=2$ ) or azathioprine-based immunosuppression $(\mathrm{n}=8)$ survived for more than 6 months (see the last entry in Table 79.3$)^{83,105}$

At the nadir of the resulting pessimism, two reproducible observations, first in dogs and then in humans, were made at the University of Colorado. Taken together, these events profoundly shaped future developments in transplantation of all organs and eventually of bone marrow. The observations were encapsulated in the title of a report published in October 1963: "The Reversal of Rejection in Human Renal Homografts With the Subsequent Development of Homograft Tolerance. ${ }^{30}$

The reversal was readily accomplished by temporarily adding unprecedented high doses of prednisone $(200 \mathrm{mg} /$ day) to baseline immunosuppression with azathioprine. The evidence that the live donor kidneys had self-induced tolerance under an umbrella of immunosuppression was equally clear. Most of the recipients had a subsequent progressively diminishing need for immunosuppression, usually to doses lower than those that initially failed to prevent rejection. The tolerance was complete enough to allow the patients to go home to an unrestricted environment. Nine of the first 10 of these kidney recipients achieved prolonged graft survival, ${ }^{30}$ including 2 who bear the longest continuously functioning allografts in the world today (more than 35.5 years) and have been free from immunosuppression for 32 and 4 years, respectively. ${ }^{106}$

The practical as well as theoretical implications of these observations were recognized throughout the report:

A state of relative immunologic non-reactivity seems to have been produced which has lasted for as long as 6 months.... It is not known whether this is due to a change in the antigenic properties of the homograft, or to an alteration in the specific [host] response to the stimulus of the grafted tissues. The apparent host-graft adaptation does, however, provide some hope for prolonged functional survival. ... It would seem probable that the [therapeutic] principles, as defined with the kidney, can eventually be applied to other organ homografts. .. The prior knowledge that a rejection crisis is almost a certainty and that it usually can be managed by relatively conservative means should serve as a deterrent to the excessive use of measures that may cause fatal bone marrow depression. . . It is also conceivable that the avoidance of a primary host-graft reaction by these means [excessive immunosuppression] would prevent the adaptive process. ${ }^{30}$

At the time this bellwether series was compiled between the autumn of 1962 and April 1963, the only other active 
clinical transplantation programs in the United States were in Richmond (directed by David Hume) ${ }^{107}$ and at the Peter Bent Brigham Hospital in Boston (directed by Joseph Murray and John Merrill). ${ }^{105}$ The historically important program of Willard Goodwin at the University of Califomia at Los Angeles (UCLA; see earlier ${ }^{89}$ ) had been closed because all the recipients died in less than 5 months. In Europe, TBI briefly remained the preferred treatment at the long-standing Paris centers of Jean Hamburger and Rene Kuss, while Michael Woodruff of Edinburgh had begun testing azathioprine. ${ }^{108}$

The results in the Colorado series, and more importantly an exact description of the strategy that had been used to induce variable degrees of incomplete tolerance (Table 79.4), created a surge of new activity. Within 12 months, new kidney transplant centers proliferated in North America and Europe. Most of these second-generation programs remain in operation today.

The observations in the original kidney recipients were promptly confirmed. However, the proposed explanation for these successes (i.e., graft alteration plus loss of specific immunological responsiveness) $)^{30}$ was controversial and remained so for the next three decades (see the section, "Allograft Acceptance Versus Acquired Tolerance"). Except for reports from the University of Colorado, the term tolerance was studiously avoided from 1964 onward in referring to the long-surviving dogs and human kidney recipients that were evident by the end of 1963 .

The article most often quoted as contravening tolerance was that of Murray et al., ${ }^{102}$ despite the fact that, as the authors took pains to make clear, the evidence in their report was inconclusive and involved only two canine experiments of a potentially crucial nature. The two long-surviving dogs had been given renal homografts 9 and 18 months previously and had been treated for most of these periods with one of the purine analogues. Renal function was deteriorating at the time contralateral kidneys from the original donors were transplanted. The second organs were rejected after 23 and 3 days, respectively, as would be expected.

In commending Murray's 1964 report and conclusions, Medawar wrote ${ }^{109}$ :

There is, however, something special about renal homografts, as [Michael] Woodruff's appraisal in this volume makes very clear. A synoptic survey of more than 1000 renal homografts in dogs carried out by Murray and his colleagues (Murray, Ross Sheil, Moseley, Knight, McGavic \& Dammin, 1964/102 has shown that foreign kidneys do sometimes become acceptable to their hosts for a reason other than acquired tolerance in the technical sense.... There has been an adaptation of some kind ... a possibility Woodruff has long urged us not to overlook ${ }^{110,111}$ though there is no reason to believe it an antigenic adaptation.

TABLE 79.4. Empircal Therapeutic Dogma of Immunosuppression.

\begin{tabular}{lc}
\hline Ingredients of strategy & Baseline agents \\
\hline $\begin{array}{l}\text { Baseline therapy } \\
\text { Secondary adjustments of prednisone dose, or }\end{array}$ & Azathioprine \\
antilymphoid agents & Cyclosporine \\
Case-to-case trial (and potential error) of weaning & Tacrolimus \\
\hline $\begin{array}{l}\text { "Alone or with prophylactic prednisone. Equivalent results were obtained with } \\
\text { cyclophosphamide instead of azathioprine. }\end{array}$ \\
bI3,174
\end{tabular}

Medawar continued ${ }^{109}$ :

One possible explanation is the progressive and perhaps very extensive replacement of the vascular endothelium of the graft by endothelium of host origin, a process that might occur insidiously and imperceptibly during a homograft reaction weakened by immunosuppressive drugs.... Another possibility, raised by R.Y. Calne (though not mentioned by him in his contribution to this volume) is the laying down of a protective coat of host antibody on the endothelial inner surface of the graft.... an explanation which would classify the phenomenon under the general heading of "enhancement."

These disclaimers notwithstanding, the commonality of the rejection barrier for different organs was self-evident. So was the likelihood that the means of inducing acceptance of one organ could be used for all the others. ${ }^{112}$ There also was evidence from earlier experiments that a liver allograft could protect other donor tissues and organs. It had been noted in 1962 that intestine and pancreas had very little histopathological evidence of rejection in untreated canine recipients if they were components of multivisceral allografts that also included the liver. ${ }^{113}$ The observations were confirmed 30 years later in a rat version of the same multivisceral procedures. ${ }^{114,115}$

Most convincingly at an experimental level, it was shown in 1964 that orthotopic canine liver allografts could induce and maintain their own acceptance far more frequently and permanently than renal allografts, even with a treatment course of azathioprine as short as 4 months. ${ }^{116,117}$ Soon thereafter, spontaneous engraftment was demonstrated after liver transplantation in untreated outbred pigs, ${ }^{118-122}$ many of which passed through self-resolving rejection crises. ${ }^{121,123,124}$

Thus, it already was clear by 1964-1965 that the liver is the most tolerogenic organ. In the late 1960 s and early 1970s, Calne, Zimmerman, and Kamada formally proved that the liver tolerization extended to other donor tissues transplanted at the same time or later, first in untreated outbred pigs ${ }^{125}$ and then without immunosuppression in selected rat strain combinations. ${ }^{126-128}$ Although they were important, the experimental studies with hepatic allografts only affirmed the conclusion reached with the 1962-1963 experience in clinical renal transplantation, suggesting that all organs were capable of inducing tolerance. Just as with liver allografts, the selfinduction of donor-specific tolerance by heart and kidney allografts without the aid of immunosuppression was later demonstrated by Corry et al. ${ }^{129}$ and Russell and coworkers ${ }^{130}$ in selected mouse strain combinations.

The key mechanism of kidney-induced allograft acceptance was suggested as early as 1964 to be clonal exhaustion. $^{131}$ This concept was developed ${ }^{132}$ more fully for liver allografts in the illustration and caption reproduced in Figure 79.2, published in 1969. Induction of the activated clone by alloantigen was depicted via host macrophages rather than by antigen-presenting dendritic cells, which would not be described ${ }^{133}$ until 1973. In the text accompanying the figure, it was pointed out that exhaustion and deletion of an antigenspecific clone had been postulated by Schwartz and Dameshek as early as 1959 to be the mechanism of the tolerance to heterologous protein induced in rabbits with the aid of 6-mercaptopurine. ${ }^{90}$ In addition, Simonsen had suggested in 1960 that clonal exhaustion induced by allogeneic 


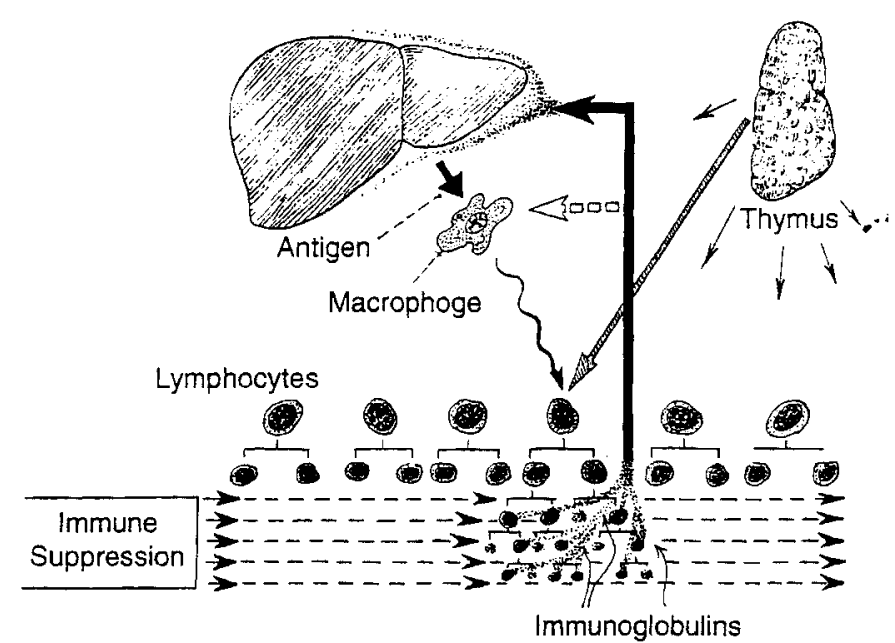

FIGURE 79.2. Hypothesis published in 1969 of allograft acceptance by clonal exhaustion. Antigen presentation was depicted via the macrophages rather than by the dendritic cells /which had not yet been described). A gap in this hypothesis was the failure to stipulate the location of the immune activation. (From Starzl, ${ }^{132}$ by permission of W.B. Saunders Co.)

splenocytes could lead to the acquisition of tolerance in adult animals in the absence of immunosuppression. ${ }^{134}$

The error of making a semantic distinction between tolerance and graft acceptance was understandable. The picture that had emerged from the remarkable accomplishments with clinical kidney transplantation between January 1959 and the spring of 1963 was not a product of new insight in immunology. Instead, successful organ transplantation was an intellectually troubling and inexplicable violation of the immunological rules of the time. The revolution in immunology that had already began, and would continue for the next third of a century, did little to change this view.

The Burnet antibody hypothesis of clonal selection (see earlier ${ }^{13}$ ) was validated and extended to cellular immunity by the late $1950 \mathrm{~s},{ }^{135-137}$ but this had minimal influence on the clinical development of transplantation; neither did many other key advances in immunology that were either contemporaneous with or came after the rise of organ transplantation. The role of the thymus in the ontology of the immune system and in the postnatal immune function of rodents was

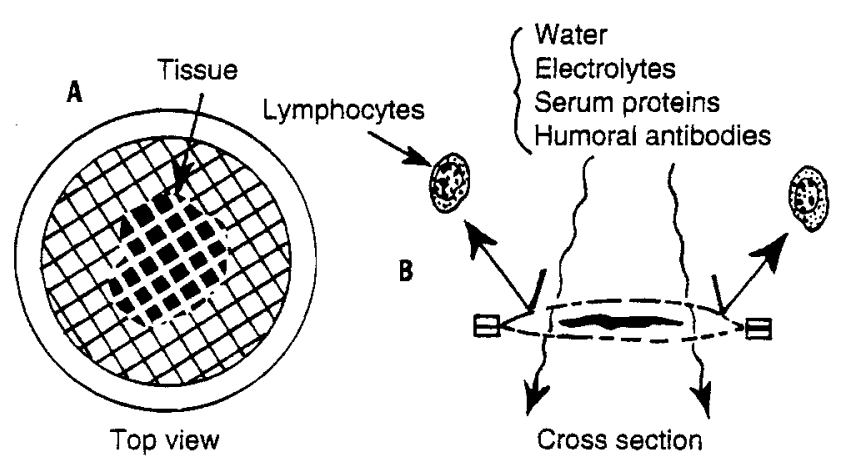

FIGURE 79.3. Schematic representation of diffusion chamber used in studies by Algire, ${ }^{144}$ from which he concluded that lymphocytes were the cellular agents of allograft rejection. (From Starzl and Butz, ${ }^{146}$ by permission of Surgical Clinics of North America.) discovered in 1961 (by Jacques Miller ${ }^{138,139}$ ). However, in humans thymectomy did not significantly alter either the early or late course of kidney transplant recipients. ${ }^{140,141} \mathrm{Lym}$ phocytes were not formally assigned a function until 1963 /by James Gowans ${ }^{142,143}$ \}, although workers in transplantation were aware several years earlier that these mononuclear leukocytes were the cellular agents of allograft rejection ${ }^{144-146}$ (Fig. 79.3). By the time the distinction was clearly established between $\mathrm{T}$ and $\mathrm{B}$ lymphocytes, transplantation was an established specialty of clinical medicine.

Thus, the ascension of organ transplantation came as a surprise to most immunologists. Even as the clinical advances had begun to unfold, Burnet ${ }^{137}$ had written in the New England Journal of Medicine that, "Much thought has been given to ways by which tissues or organs not genetically and antigenically identical with the patient might be made to survive and function in the alien environment. On the whole, the present outlook is highly unfavorable to success." Pessimism also was deeply ingrained in conventional practitioners of medicine. Well into the 1960 s, editorials were published in major clinical journals that questioned both the inherent feasibility and the ethical basis of transplantation procedures. ${ }^{147}$ As a consequence, transplantation acquired a renegade image, a burden soon compounded by difficulties in extending its reach to the replacement of vital organs other than the kidney.

One dilemma, as it was perceived at the time, is shown in Figure 79.4. ${ }^{148}$ It was feared that chronic drug immunosuppression powerful enough to prevent organ allograft rejection would render the recipient hopelessly vulnerable to indigenous and environmental pathogens. Reports of infectious disease complications in the early Colorado recipients ${ }^{149}$ and elsewhere gave warning that dire consequences might, in time, be in store for all recipients. It also was suspected that immune surveillance to tumors would be eroded, a possibility that was verified but by 1958 was shown to be manageable. ${ }^{150-152}$

Autopsy studies in failed clinical cases revealed a typical pattern. Infections for which specific antibiotics were available could be largely controlled. However, opportunistic

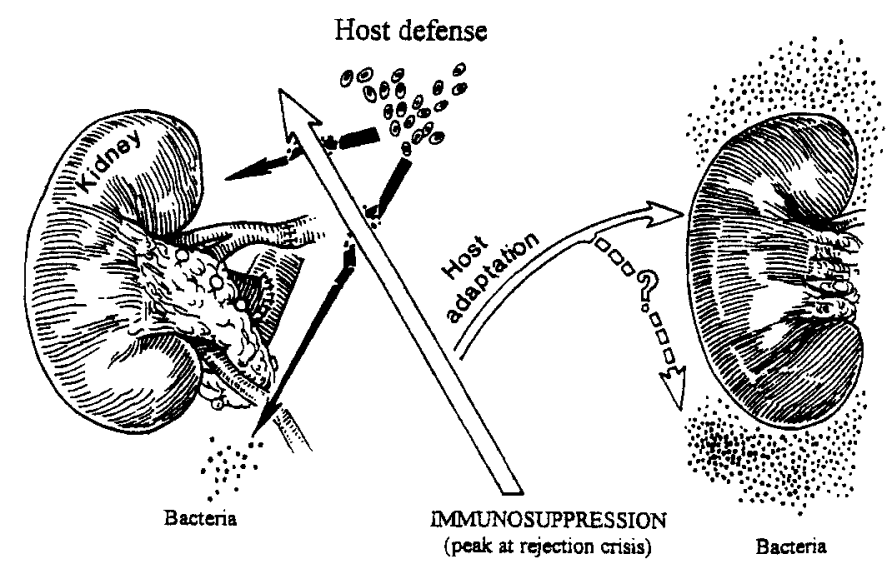

FIGURE 79.4. The original legend for this figure was "Possible mechanisms of simultaneous loss of host reactivity to specific strains of endogenous bacteria, as well as to the alien renal tissue." [From Starzl et al., ${ }^{148}$ by permission of Surgery (St. Louis).] 
microorganisms of normally low pathogenicity were overrepresented and appeared at autopsy to be the main cause of death. ${ }^{153}$ Of these infections, cytomegalovirus (CMV) was the most common and lethal. The presence of Pneumocystis carinii as a coinfection with $\mathrm{CMV}^{154}$ premonstrated the lethal role of this combination of infectious agents in the acquired immunodeficiency syndrome (AIDS) epidemic in the nontransplant population that lay two decades ahead.

\section{The Maturation of Transplantation}

Although it was entirely empirical, the practical framework required for the maturation of clinical transplantation was essentially complete by the end of 1963 . Without knowing either the nature of the normal immune response or the way in which it had been subverted, surgeons had learned how to reliably redirect the immune response with the aid of immunosuppression. Surgical (see opening section) and preservation techniques (see later) had been developed for transplantation of all the organs; these are used currently with only minor modifications. Yet, the field of organ transplantation stalled and now entered a phase that was euphemistically termed consolidation. The reason was the failure to find improved means of exploiting the principles for control of rejection that had been established with azathioprine and prednisone (see Table 79.4).

\section{Improved Immunosuppression}

\section{ANTILYMPHOID STRATEGIES}

Between 1963 and 1979, the only significant advance in clinical immunosuppression was the introduction in 1966 of heterologous antilymphocyte globulin (ALG). ${ }^{155,156}$ This step was a logical extension of Gowan's demonstration of the immunosuppressive effects of lymphoid depletion with thoracic ducr drainage (TDD) in rats. ${ }^{142,143}$ In fact, Woodruff and Anderson showed that TDD and antilymphocyte serum (ALS) had additive effects. ${ }^{157}$

Franksson and Blomstrand used TDD clinically in 1963 to treat kidney recipients in Stockholm, ${ }^{158}$ an approach that resurfaced periodically during the next two decades (summarized in Ref. 1591. Conditioning with TDD before transplantation clearly reduced the frequency and vigor of kidney rejection, but 30 days of pretreatment were required in humans, ${ }^{159,160}$ compared to the 5 days in Gowan's rats. ${ }^{142,143}$ However, the inconvenience, complexity, and expense of IDD precluded its wide use. ${ }^{160}$ For the same reasons, total lymphoid irradiation (TLI), ${ }^{161}$ which also was an effective means of lymphoid depletion but with the disadvantage that it was not quickly reversible, did not have a lasting impact on clinical transplantation. ${ }^{162,163}$

In contrast, ALG was a major turning point for two reasons. First, it was a critical factor in the emergence of extrarenal organ transplantation. Second, it was a prototype drug from which numerous variations evolved. The concept of mitigating cellular immunity with heterologous antibodies had been proposed by Ilya Metnikoff at the end of the 19 th century ${ }^{164}$ and was revitalized by Inderbitzen ${ }^{165}$ and Waksman et al. ${ }^{166}$ before Woodruff and Anderson, ${ }^{157}$ Levey and Medawar, ${ }^{167}$ Monaco, Wood, and Russell, ${ }^{168,169}$ and other surgeons recognized its potential role in clinical transplantation.

In most of the animal investigations up to 1963 , the antilymphocyte antibodies were raised in rabbits, and in all cases the raw ALS was administered. In preparation for clinical trials, horse antidog ALS was prepared, and the active moiety was refined from the gamma globulin. ${ }^{155}$ After the product was shown to inhibit or reverse rejection in the canine kidney and liver transplant models, ${ }^{156}$ comparable horse antihuman ALG was produced from the serum of horses that had been immunized with leukocytes separated from human lymphoid organs (lymph nodes, spleen, thymus). ${ }^{155}$

The first clinical trial of ALG began in 1966. Daily injections were given to kidney recipients for 1 to 4 postoperative weeks as a short-term adjunct to continuous azathioprine and prednisone. ${ }^{156}$ After encouraging results were obtained in the kidney trial, liver transplantation was resumed, with long survival of several patients. The successful liver replacements ${ }^{19}$ in the summer of 1967 expanded the horizon of transplantation to the other vital extrarenal organs. Within the succeeding 27 months, heart, ${ }^{20,21}$ lung, ${ }^{22}$ and pancreas transplantation ${ }^{23}$ also were accomplished using variations of the treatment shown in Table 79.4. As had happened with kidney centers in 1963, a wild proliferation of extrarenal (particularly heart) programs followed. However, almost all of them closed within the next 2 years because of an overwhelming failure rate.

Polyclonal ALG was never used in more than about $15 \%$ of kidney transplant cases reported to registries up to the early 1980s, in part because it was in no sense a standardized drug like azathioprine and prednisone. Although the use by Najarian and Simmons ${ }^{170}$ of known numbers of cultured human lymphoblasts for accurately timed horse immunization improved the predictability of the ALG potency, batch-tobatch variations in potency remained problematic. "Antibody therapy" came of age with production of monoclonal antibodies made feasible by the hybridoma technology of Kohler and Milstein. ${ }^{171}$ The first-generation murine monoclonal antibody muromonab CD3 (Orthoclone OKT3) was directed at the $\mathrm{CD} 3$ antigen present on all $\mathrm{T}$ lymphocytes. ${ }^{172}$ Subsequent antibody preparations, which include less-immunogenic humanized "hybrids," have been directed at discrete targets such as T-cell subsets, adhesion molecules, and T-cell or interleukin 2 receptors. However, when these agents are used, the "induction" strategy has been essentially the same as with the original crude ALG.

\section{CYCLOPHOSPHAMIDE}

Although the experience in this middle era, defined by the first triple-drug regimen, demonstrated the feasibility of transplanting the vital extrarenal organs, it also indicated that further progress would require better baseline immunosuppression. Substitution of the alkylating agent cyclophosphamide for azathioprine was such an effort. ${ }^{173}$ The characteristic cycle of immunological confrontation and resolution leading to graft acceptance was no different with this drug than with azathioprine-based therapy. However, when the results with kidney and liver transplantation were almost identical to those using azathioprine but at a higher price of complica- 
tions, the trials were discontinued. ${ }^{174}$ Although cyclophosphamide thereby became a footnote in the history of organ transplantation, it continued to play a role in bone marrow transplantation.

\section{CyCLOSPORINE}

Another decade would pass before the greater potency of cyclosporine would make transplantation of the liver and other cadaveric organs (including the kidney) a reliable service. Cyclosporine, an extract from the fungi Cylindrocarpon lucidum and Trichoderma polysporum, was discovered by Dreyfuss et al ${ }^{175}$ and characterized biochemically by Ruegger et al. ${ }^{176}$ and Petcher et al. ${ }^{177}$ It was shown to be immunosuppressive by Borel et al. ${ }^{178-180}$ with multiple test systems, including skin allotransplantation in mice, rats, and guinea pigs.

The drug depressed humoral and cellular immunity and had a preferential and quickly reversible action against $T$ lymphocytes. Unlike azathioprine and cyclophosphamide, these effects were not accompanied by bone marrow depression or other prohibitive organ toxicity. The ability of cyclosporine to prevent or delay rejection of hearts, kidneys, livers, or pancreases was promptly shown in rats, rabbits, dogs, and pigs by Kostakis, ${ }^{181}$ Calne, ${ }^{182-184}$ and Green ${ }^{185}$ and their associates. There was no hint in these preclinical studies that nephrotoxicity would be the dose-limiting factor in human trials.

The toxicity profile of cyclosporine became evident in Calne's initial evaluation ${ }^{186,187}$ of cyclosporine in human recipients of 32 kidneys, 2 pancreases, and 2 livers, reported in 1978-1979. The ability of the drug to prevent rejection, alone or in combination with myelotoxic drugs, exceeded anything previously seen. However, the requisite overdosage caused multiple serious side effects: nephrotoxicity, neurotoxicity, diabetogenicity, a $10 \%$ incidence of B-cell lymphoma, and cosmetic changes (gingival hyperplasia, facial brutalization, and hirsutism).

When cyclosporine in lower doses was combined with prednisone in the treatment algorithm shown in Table 79.4, the prognosis of cadaver kidney recipients was improved, ${ }^{188}$ and transplantation of the liver, ${ }^{189}$ heart, ${ }^{190,191}$ and lungs ${ }^{192}$ was brought to the level of a practical clinical service. Recapitulating the aborted avalanche of 1967 , many new extrarenal programs appeared, joining the five extant liver centers (Denver [from 1963], Cambridge [1968], Hannover [1972], Paris [1974], and Groningen [1977]) and the single remaining heart program [Stanford [from 1968]]. This time, most of the programs flourished.

\section{TACROLIMUS}

Cyclosporine was the unchallenged baseline immunosuppressant for all varieties of transplantation until it was shown in 1989 that intractably rejecting liver allografts could be regularly rescued by replacing cyclosporine with tacrolimus, ${ }^{193}$ an extract of Streptomyces tsukubaensis discovered by Kino et al. ${ }^{194}$ Tacrolimus was tested initially in a rat cardiac transplant model by Ochiai et al. ${ }^{195}$ and soon thereafter by Murase et al. in rats ${ }^{196,197}$ and by Todo et al. in dogs ${ }^{198,199}$ and subhuman primates. ${ }^{199,200}$
TABLE 79.5. Nonimmunological Profile.

\begin{tabular}{lcc}
\hline & FK 506 & CyA \\
\hline Nephrotoxicity & $++^{\mathrm{a}}$ & ++ \\
Neurotoxicity & + & + \\
Diabetogenicity & + & + \\
Growth effects & & \\
-Hirsutism & 0 & +++ \\
Gingival hyperplasia & 0 & ++ \\
Facial brutalization & 0 & + \\
Hepatotrophic effects & ++++ & +++ \\
Gynecomastia & 0 & + \\
Other metabolic effects & & ++ \\
$\quad$ Cholesterol increase & $0^{b}$ & ++ \\
Uric acid increase & $+?$ & \\
\hline
\end{tabular}

All effects dose-related; $+1+$, worst.

'Less hypertension.

'In rats, Van Thiel has shown an increase in cholesterol synthesis and serum concentration.

Source: From Starzl et al. ${ }^{310}$

In addition to numerous confirmatory reports of its ability to rescue about $75 \%$ of intractably rejecting human liver allografts, ${ }^{201}$ tacrolimus could salvage an equal proportion of rejecting hearts, kidneys, and other organs. ${ }^{202}$ In virtually all such cases, a switch back to cyclosporine was never made. Consequently, clinical trials using tacrolimus primarily were begun. . $02-204^{2}$

By early 1990, more than 150 liver, kidney, heart, and heart-lung recipients had been treated from the time of transplantation with immunosuppression based on tacrolimus (FK 506) rather than cyclosporine ( $\mathrm{CyA}){ }^{205}$ It was learned from this experience that the three major side effects of the drug (nephrotoxicity, neurotoxicity, and diabetogenicity) were comparable to cyclosporine. Hypertension and hyperlipidemia were less than in historical cyclosporine controls. The cosmetic effects of cyclosporine were not seen (Table 79.5).

The effective use of both cyclosporine and tacrolimus required the same pattern recognition and therapeutic response that have guided organ transplantation since its inception (see Table 79.4). The dose ceilings of the four widely used baseline immunosuppressants were imposed by toxicity: myelotoxicity for azathioprine and cyclophosphamide and the more complex side effects shown in Table 79.5 for cyclosporine and tacrolimus. The dose floors were revealed by the breakthrough of rejection. Because none of the four drugs could be used alone, they had to be incorporated into "cocktails" in which the requisite doses of the individual drug constituents were determined on a case-by-case basis by trial and error. Dose-maneuverable prednisone has remained a constant for 36 years, but steroid dependence declined with the more potent baseline agents.

The lead organ for azathioprine was the kidney. The developmental responsibility for cyclosporine was shared by the kidney and liver, while the liver bore the principal burden for tacrolimus. ${ }^{193,201,203,205-209}$ However, progress with one kind of organ allograft inevitably meant progress for all. Thus, survival of each kind of organ graft rose in the same three distinct leaps between 1962 and 1998 (Fig. 79.5). With tacrolimus, the intestine was no longer a "forbidden" organ. ${ }^{210-212}$ 

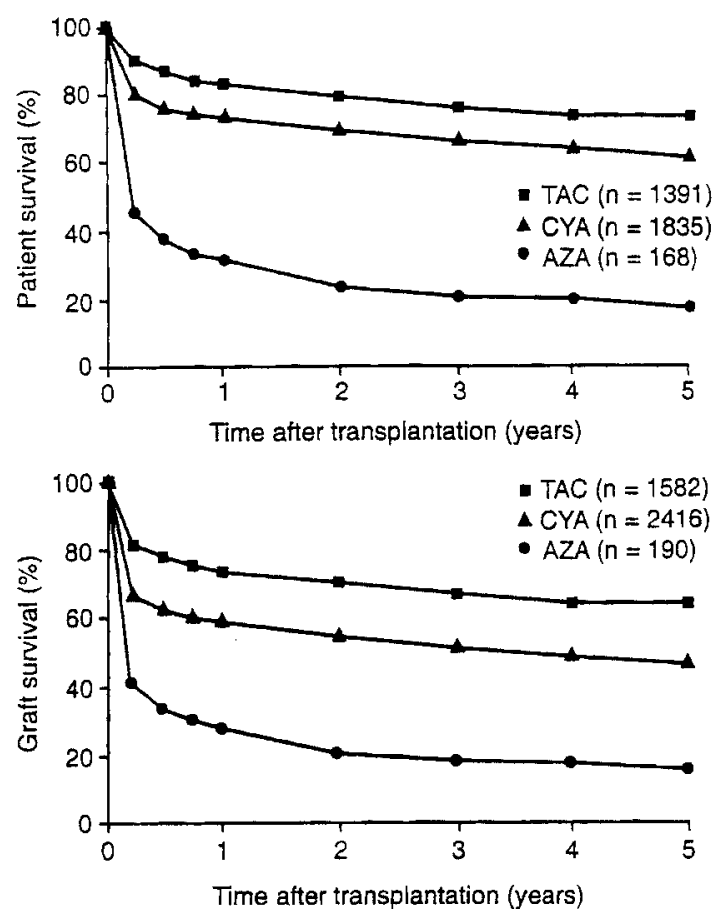

FIGURE 79.5. The three eras of orthotopic liver transplantation at the universities of Colorado (1963-1980) and Pittsburgh (1981-1993), defined by azathioprine (AZA), cyclosporine (CYA), and FK 506 (tacrolimus)-based (TAC) immunosuppression. The same stepwise improvement was seen with all organs. Top: Patient survival. Bottom: Graft survival. These results were about $10 \%$ lower than patient survival in both the cyclosporine (1980-1989) and tacrolimus eras (1989-1993) because of effective retransplantation, an option that did not exist previously.

\section{The Ripple Effect}

\section{Organ Procurement and Preservation}

The sudden arrival of clinical kidney transplantation in 19621963 was so unexpected that little collateral research or other formal preparation had been made to preserve organs. Although kidneys were successfully transplanted in the pioneer identical twin cases despite protracted periods of warm ischemia, the maturation of clinical transplantation could not proceed without effective organ conservation. This was accomplished at first with total body hypothermia of living volunteer kidney donors, ${ }^{213}$ using methods developed by cardiac surgeons for open-heart operations. ${ }^{214}$ In the experimental laboratory, Lillehei et al..$^{39}$ simply immersed the excised intestine in iced saline before its autotransplantation, a method also used by Shumway in developing experimental and clinical heart and heart-lung transplantation. ${ }^{44-46}$ Thus, the principle of hypothermia was understood at an early time, although it was not efficiently applied.

The first major innovation in hypothermia was in the laboratory, when canine liver allografts were cooled by infusion of chilled fluids into the vascular bed of hepatic allografts via the portal vein. ${ }^{42}$ Before this time, survival of dogs after liver transplantation was almost never obtained, while afterward success became routine. In a logical extension to clinical kidney transplantation, the practice was introduced in 1963 of infusing chilled lactated Ringer's or low molecular weight dextran solutions into the renal artery of kidney grafts immediately after their removal. ${ }^{215}$

Today, intravascular cooling is the first step in the preservation of all whole-organ grafts. For cadaver donors, this is most often done in situ by some variant of the technique described by Marchioro et al. ${ }^{216}$ (Fig. 79.6). This method for the continuous hypothermic perfusion of cadaveric livers and kidneys was used clinically long before the acceptance of brain death. Ackerman and Snel11217 and Merkel, Jonasson, and Bergan ${ }^{218}$ popularized the simpler core cooling of cadavers with cold electrolyte solutions infused into the distal aorta.

\section{Organ Procurement}

Until 1981, transplantation of the extrarenal organs was an unusual event. By late 1981, however, it had become obvious that liver and thoracic organ transplant procedures were going to be widely used. A method of multiple-organ procurement was required by which the kidneys, liver, heart, and lungs or various combinations of these organs could be removed without jeopardizing any of the individual organs. "Flexible techniques" were developed ${ }^{219,220}$ that were quickly adopted worldwide. With the methods, all organs to be transplanted are cooled in situ, rapidly removed in a bloodless field, and dissected on a back table. The sharing of organs from a common donor by recipient teams from widely separated centers became routine by the mid-1980s.

\section{Ex Vivo Perfusion}

Extension of the safe period after initial cooling has followed one of two prototype strategies, developed either with kidneys

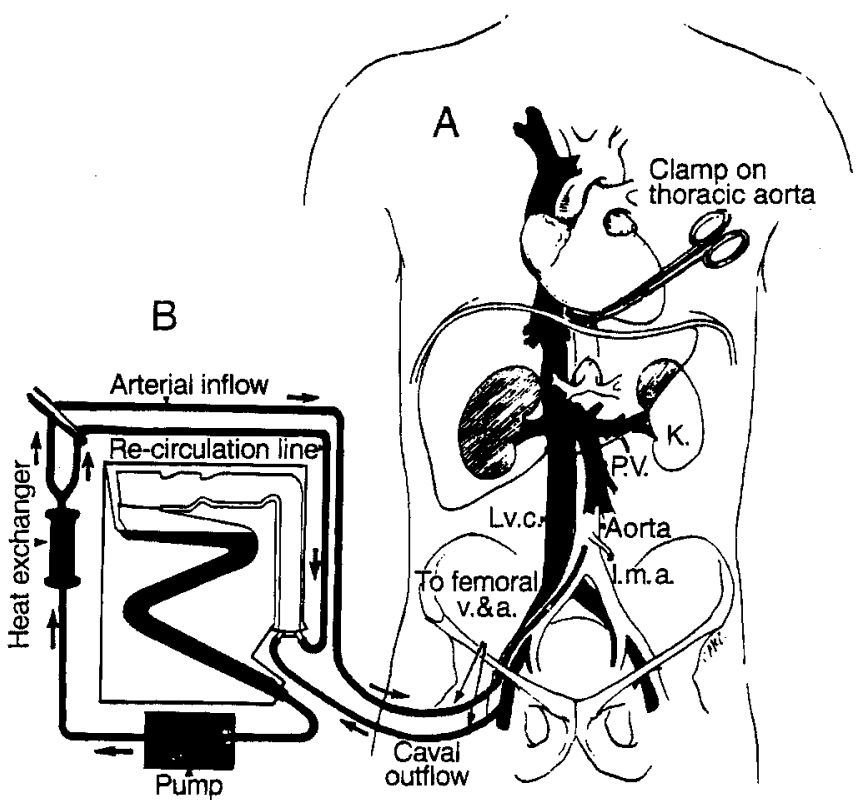

FIGURE 79.6. Technique of extracorporeal perfusion with a heartlung machine described by Marchioro et al. ${ }^{216}$ Catheters are inserted via the femoral vessels into the aorta and vena cava as soon as possible after death. The extracorporeal circuit is primed with a glucose or electrolyte solution to which procaine and heparin are added. The cadaver is thus anticoagulated with the first surge of the pump. Temperature control is provided by the heat exchanger. Cross-clamping the thoracic aorta limits perfusion to the lower part of the body. (From Starzl, ${ }^{215}$ by permission of W.B. Saunders Co.) 
or livers and applied secondarily to other organs. One approach, which was extensively evaluated by Alexis Carrel and the aviator Charles A. Lindbergh, was to simulate normal physiological conditions with ex vivo perfusion techniques. ${ }^{221}$ This concept was modified by Ackerman and Barnard, ${ }^{222}$ who provided the isolated organs with a continuous low-flow renal arterial circulation using a perfusate primed with blood and oxygenated within a hyperbaric oxygen chamber. This technique also permitted good preservation of hepatic allografts for as long as a day. ${ }^{223}$ However, the complexity of the method precluded its general use.

The elimination of the hemoglobin and hyperbaric chamber components by Belzer et al. ${ }^{224}$ resulted in satisfactory kidney preservation for as long as 2 to 3 days. The asanguinous perfusion technique eventually was abandoned in most kidney transplant centers when it was learned that the quality of 2-day preservation was not better than with the simpler "slush" methods (see following). Nevertheless, it is expected that refinement of perfusion technology will someday permit true organ banking.

\section{Slush Preservation}

With the so-called static methods, fluids of differing osmotic, oncotic, and electrolyte composition are infused into the allograft before placing it in a refrigerated container. ${ }^{225,226}$ The solution described by Collins, Bravo-Shugarman, and Terasaki ${ }^{225}$ (which resembles intracellular electrolyte concentrations) or modifications of it were used for almost two decades. Renal allograft preservation was feasible for 1 to 2 days, long enough to allow tissue matching and sharing of organs over a wide geographic area. Experiments with hepatic allografts by Benichou et al. ${ }^{227}$ using the Collins-Terasaki solution and by Wall et al. ${ }^{228}$ with the plasma-like Schalm solution led directly to liver sharing between cities, but with a time limitation of only 6 to $8 \mathrm{~h}$.

The introduction for liver transplantation of the University of Wisconsin (UW) solution by Belzer, Jamieson, and Kalayoglu, ${ }^{229,230}$ was the first major development in static preservation since the Collins-Terasaki solution. ${ }^{231}$ The superiority of the UW solution for preservation of the kidney and other organs was promptly demonstrated in experimental models and confirmed in clinical trials. ${ }^{232-237}$ The UW preservation doubled or tripled the time of safe preservation of the various allografts, making national and international sharing of most organs an economical and practical objective.

\section{The Life Sciences}

While occupying its own unique niche, transplantation has drawn from and in turn enriched all the other basic and clinical scientific disciplines. Aside from changing the philosophy by which organ-defined specialties of surgery and medicine are practiced, transplantation grew parallel with, and contributed in a major way to, advances in immunology, pharmacology, oncology (e.g., the role of tumor immune surveillance $^{152,238}$, infectious disease, intensive care, and anesthesiology. Study of each of the different kinds of allografts has yielded an organ-specific harvest of special information. Examples include a better understanding of diabetes mellitus with pancreas transplantation and of the effects of denerva- tion on cardiopulmonary function with heart and lung transplantation.

The liver became the key organ in unmasking the secrets of acquired tolerance because of its large content of immunocompetent leukocytes/see earlier and the section, "Allograft Acceptance Versus Acquired Tolerance"). In addition, the functional complexity of the liver as well as its metabolic interactions with other abdominal viscera have made hepatic transplantation a "mother lode" for physiological studies. ${ }^{239}$

In the course of determining the optimal revascularization of auxiliary livers transplanted to ectopic sites or to the normal location, ${ }^{42,240,241}$ it was found that endogenous insulin is a liver growth factor, ${ }^{242,243}$ the first such hepatotrophic factor to be identified. Using transplantation-derived models, a family of other molecules was delineated with insulinlike hepatotrophic properties. ${ }^{244}$ Eventually, the gene was discovered that expresses one of these laugmenter of liver regeneration). ${ }^{245-247}$ The hepatotrophic factors, most of which are cytokines (e.g., hepatocyte growth factors [HGFs]), regulate liver size, structure, regeneration, and metabolic homeostasis.

Studies of hepatotrophic physiology led directly or indirectly to liver replacement for cure of more than two dozen hepatic-based inborn errors of metabolism, ${ }^{248}$ including familial hypercholesterolemia. ${ }^{249,250}$ The role of hepatic transplantation in first suggesting, and then proving, that the liver governs cholesterol metabolism has been described elsewhere. $238,249-251$ Elucidation of the cellular and molecular mechanisms was rewarded by bestowal of the 1985 Nobel Prize to Brown and Goldstein (see Table 79.2).

\section{Immunological Screening}

The importance of the genetically determined major histocompatibility complex ( $\mathrm{MHC}$ ) in determining the immune response to allografts was evident from investigations by George Snell in inbred mice, ${ }^{252}$ which in turn derived from the work of Peter Gorer /see "the seminal influence of Gorer and Snell" 253 . However, the information was not clinically applicable. Thus, immunological screening of donors and recipients was not done during the volatile 1959-1963 developmental period. ${ }^{1}$ The possibility of tissue matching did not begin to emerge until the discovery in 1958 by Dausset of the first human leukocyte antigen (HLA) ${ }^{254}$ and the discovery in the same year by Van Rood et al. ${ }^{255}$ of antileukocyte antibodies (soon shown to be HLA directed) in the sera of pregnant women.

The report in 1964 by Terasaki and McClelland ${ }^{256}$ of the microcytotoxicity test, with which HLA antigens could be detected serologically in minute quantities of sera, was a critical development in moving forward with the classification of the antigens.

\section{The Crossmatch Principle}

As it turned out, the greatest impact of pretransplant tissue matching has been the prevention of hyperacute rejection by observation of $\mathrm{ABO}$ compatibility guidelines and the routine use of the cytotoxicity crossmatch. 


\section{ABO COMPATibility}

Hyperacute rejection was first observed more than 30 years ago when $A B O$-mismatched renal allografts were transplanted into patients who had preformed antigraft $A B O$ isoagglutinins. ${ }^{3,257}$ After kidneys were lost on the operating table, arteriograms of the infarcted organs showed nonfilling of the small vessels, correlating histopathologically with widespread thrombotic occlusion of the microvasculature. It was concluded that high-affinity isoagglutinins in the recipient sera had bound to $A$ or $B$ antigens in the graft vessels and parenchymal cells. This finding was consistent with rapid changes in recipient isoagglutinin titers that followed organ revascularization. The guidelines formulated from this experience ${ }^{53,257}$ were designed to avoid such antibody confrontations (see Table 79.1).

The $A B O$ rules also apply to heart, liver, and other kinds of organ transplantation. As was originally observed in 1963 with ABO-mismatched kidneys, however, ${ }^{53,257}$ not all organs placed in the hostile environment of antigraft isoagglutinins meet the same fate. In fact, the longest continuously functioning renal allograft in the world ${ }^{106}$ is a $\mathrm{B}+$ kidney donated to a then-38-year-old $\mathrm{A}+$ male recipient by his younger sister on January 31, 1963. In addition, it was learned at an early time that the liver is more resistant to antibody attack than other organs. ${ }^{258}$

In histocompatibility studies in which human volunteers were sensitized with purified A and B blood group antigens, causing variably increased titers of isoagglutinins, Rapaport et al. ${ }^{259}$ showed accelerated or hyperacute (white graft) rejection of $\mathrm{ABO}$-incompatible skin grafts transplanted to recipients with high titers. This result completed the circle of evidence indicating antigraft antibodies as the precipitating cause of hyperacute organ rejection.

\section{With Non-ABO ANTIBODIES}

In 1965, hyperacute rejection of a kidney by an ABO-compatible recipient was reported for the first time by Terasaki et al. ${ }^{260}$ Terasaki's observation that the serum of the recipient of a live donor kidney contained preformed antigraft lymphocytotoxic antibodies was promptly confirmed in similar cases by Kissmeyer-Nielsen et al. ${ }^{261}$ and others. ${ }^{262,263}$ The evidence of a cause-and-effect relationship in the single first case was so clear that Terasaki recommended and immediately introduced his now universally applied lymphocytotoxic crossmatch test. ${ }^{260,264}$

It has been shown in presensitized animals and humans that antibodies, clotting factors, and formed blood elements were rapidly cleared by the hyperacutely rejecting grafts. ${ }^{265,266}$ Local fibrinolysis from the renal vein also was a consistent finding, and in exceptional cases, there were systemic coagulopathies with disseminated intravascular coagulation (DIC) ${ }^{267,268}$ The findings are comparable to those in the Arthus reaction, inverse anaphylaxis, generalized Shwartzman reaction, and other models of innate immunity. 263,267,268

Non-HLA antibodies such as antivascular endothelial cell antibodies also have been associated with hyperacute or accelerated rejection..$^{269,270}$ The vulnerability of extrarenal organs to this kind of rejection was ultimately demonstrated experimentally ${ }^{271-273}$ and clinically. Although the liver was the most antibody-resistant, ${ }^{258}$ it also was placed at increased risk by the presensitized state. ${ }^{274}$ Hyperacute rejection also has been documented in a small number of human organ recipients in the absence of detectable antibodies. ${ }^{263,275}$

\section{Tissue Matching}

Historically, it was predicted tissue matching would have to be perfected if long-term engraftment of tissues and organs was to succeed with any degree of reliability and predictability. The prophecy was immediately fulfilled with bone marrow transplantation, in which anything less than a perfect or near-perfect match between the donor and recipient resulted in GVHD or rejection of the graft. ${ }^{26-29}$ When similar expectations were not met in studies by Paul Terasaki in kidney transplant recipients, the results initially were treated as a scientific scandal. ${ }^{276,277}$ When he later was proved to have been correct, Terasaki emerged as the father of HLA matching and as an enduring symbol of integrity.

Terasaki's investigations began with a retrospective study of the influence of HLA matching on the quality of outcome of patients bearing long-surviving kidney allografts, ${ }^{278}$ followed by a prospective trial in live donor kidney recipients treated with azathioprine and prednisone, with or without adjunct ALG. ${ }^{279}$ Consistent with the results in the classic skin graft investigations in nonimmunosuppressed healthy volunteers by Rapaport and Dausset, ${ }^{280-282}$ HLA-matched allografts had the best survival and function, least dependence on maintenance prednisone, and fewest histopathological abnormalities in routine 2-year postoperative biopsies. ${ }^{283}$ Unexpectedly, however, a cumulative adverse effect of mismatching in the kidney recipients could not be identified.

The equally imprecise prognostic discrimination of HLA matching in cadaver kidney transplant cases also was first recognized by Terasaki (with Mickey et al. ${ }^{284}$ ) and has been evident in analyses up to the present time. With the large sample sizes in United Network for Organ Sharing (UNOS) and European databases, virtually every comparison of the different levels of mismatching showed statistical significance. However, the absence of a large or consistent matching effect unless there is a perfect or near-perfect match has always been the same. In a recent study of more than 30,000 UNOS patients for whom optimal matches had been sought prospectively, approximately $85 \%$ of the cases were in the two- to five-HLA-mismatch spectrum in which 1-year survival was clustered within $3 \%$. Subsequent half-life projections thereafter were in the narrow spread of 9 to 11 years. $^{285}$

Terasaki's conclusions nearly three decades ago breathed life into the still-struggling fields of liver, heart, and lung transplantation. It was a relief to know that the selection of donors with random tissue matching would not result in an intolerable penalty. A quarter of a century passed before it could be explained why HLA matching was critical for bone marrow, but not organ, transplantation (see next section).

\section{Allograft Acceptance Versus Acquired Tolerance}

During the Festschrift at Harvard honoring Paul Russell's retirement in late November 1990, Norman Shumway told me and Leslie Brent about his text on Thoracic Transplantation for which he wanted two chapters: one explaining the 


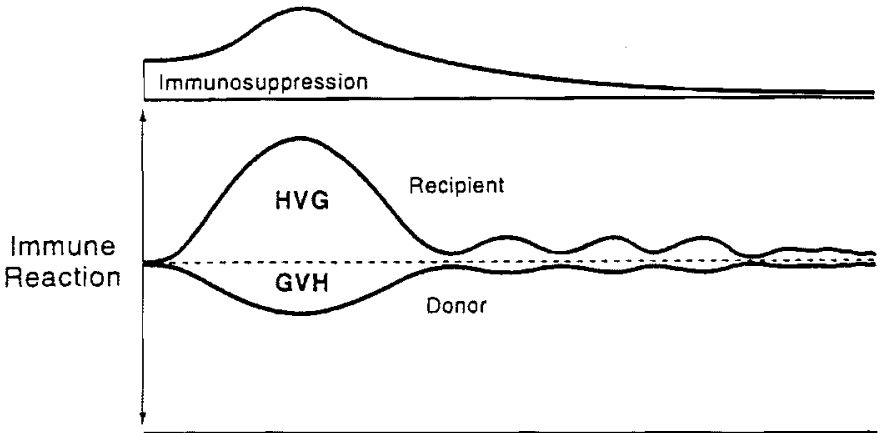

Time after Transplantation

FIGURE 79.7. Contemporaneous host-versus-graft (HVG) and graftversus-host (GVH) reactions in the two-way paradigm of transplantation immunology. Following the initial interaction, the maintenance of nonreactivity of each leukocyte population to the other is seen as a predominantly low-grade stimulatory state that may wax and wane.

classic immunological tolerance exemplified by bone marrow transplantation and the other defining the presumably different mechanisms of whole-organ allograft acceptance. On learning that $I$ thought the two were the same in principle, Shumway assigned me to the task of defending this opinion. ${ }^{286}$

Evidence was obtained first from investigation of longsurviving human liver, kidney, and other organ recipients ${ }^{31,32,287-289}$ and then from detailed confirmatory animal studies. ${ }^{290-293}$ The observation that all 30 patients tested had low-level (micro-) chimerism conformed perfectly with the hypothesis being tested that allograft acceptance involved not only chimerism but also a bidirectional immune reaction (Fig. 79.7). The relative strengths of the opposing immune reactions following organ transplantation were simply the reverse of those following bone marrow transplantation to the cytoablated recipient (summarized in Refs. 33 and 106). With this paradigm, it has been possible to view the historical milestones of clinical organ as well as bone marrow transplantation in a coherent way. ${ }^{34}$

Historically, an organ allograft had been envisioned as defenseless and vulnerable to immunological attack in proportion to its histoincompatibility (Fig. 79.8, top left). The same dogma in reverse (i.e., the host was the defenseless target) was the conventional view of bone marrow transplantation (Fig. 79.8, top right). Only two pioneer workers raised objections to the definition of transplantation immunology in terms of a unidirectional immune reaction. In 1960-1961, Simonsen $^{134}$ and then Michie, Woodruff, and Zeiss ${ }^{294}$ postulated that the two populations of immune cells in neonatally tolerant mice managed to coexist in a stable state by becoming mutually nonreactive while retaining the ability to function collaboratively (i.e., in a joint immune response to infection).

Although this heretical suggestion resembled the concept summarized in Figures 79.7 through 79.11, in 1962 the Simonsen-Woodruff hypothesis was recanted, ${ }^{295}$ ostensibly because no experimental support could be found for it. More important, however, it had been advanced in a nonreceptive climate in which "group think" had already turned in a different direction. For the next 30 years, transplantation immunity and tolerance were conceived as products of unidirectional immune reactions of the kind that could be studied in vitro by one-way mixed-lymphocyte culture techniques described by Bain, Vas, and Lowenstein ${ }^{296}$ and Bach and Hirschhorn. ${ }^{297}$

After chimerism was discovered in 1992-1993 in organ recipients, ${ }^{31-33}$ it was recognized that the interaction of the coexisting donor and recipient leukocyte populations was the common factor that underlay both the "acceptance" induced by whole-organ allografts (Fig. 79.8, bottom left) and the

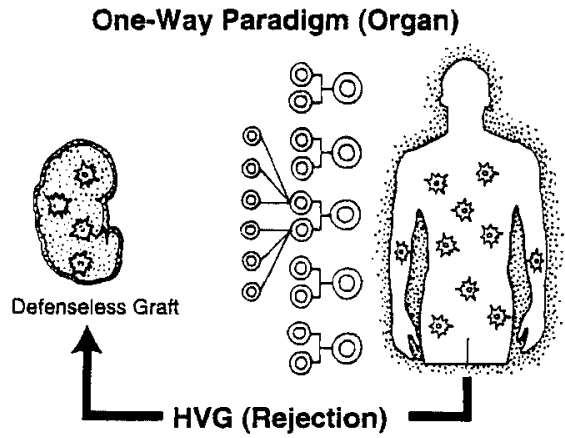

Two-Way Paradigm (Organ)

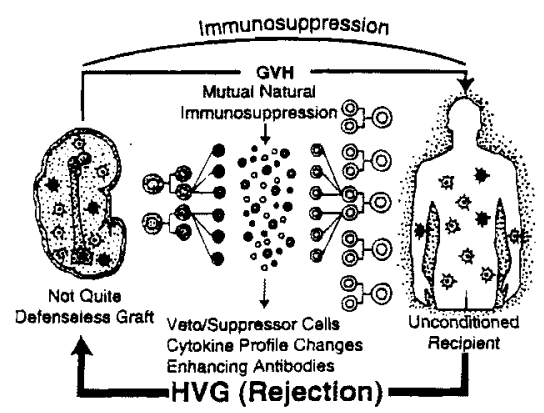

One-Way Paradigm (Bone Marrow)
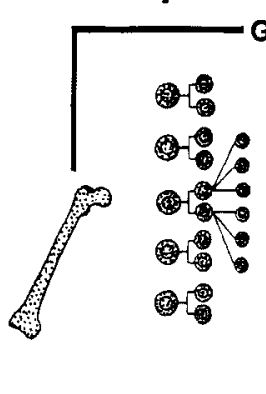

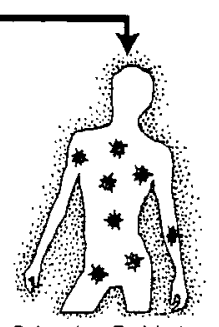

Dofenseless fiecipient

Billingham-Brent-Modawa

Cytoablation ( $\mathrm{x}$-ray, drugs)

Parent $\rightarrow$ Offspring F1 Hybito

Two-Way Paradigm (Bone Marrow)

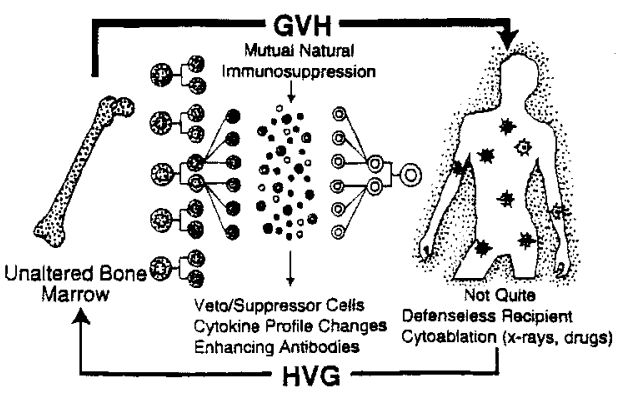

FIGURE 79.8. Top panels. One-way paradigm in which transplantation is conceived as involving a unidirectional immune reaction: left, host-versus-graft (HVG) with whole organs; right, graft-versus-host (GVH) with bone marrow or other lymphopoietic transplants. Bottom panels. Two-way paradigm in which transplantation is seen as a bidirectional and mutually canceling immune reaction that is (left) predominantly HVG with whole-organ grafts and (right) predominantly GVH with bone marrow grafts. 


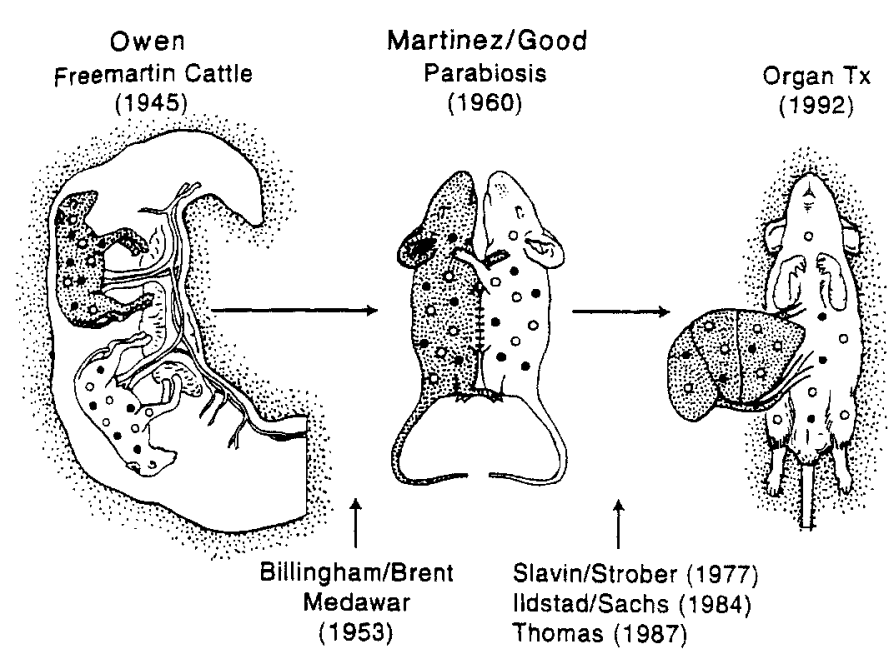

FIGURE 79.9. Continuum of chimerism from observations of Ray Owen in freemartin cattle to the discovery in 1992 of microchimerism in organ recipients.

tolerance induced with bone marrow (Fig. 79.8, bottom right). This context closed the 30-year intellectual gap between the fields of organ and bone marrow transplantation. Organ-associated chimerism then could be identified in a continuum of classic tolerance models, ${ }^{5,11,161,298-300}$ beginning with the original observations by Owen in freemartin cattle (Fig. 79.9).

\section{Organ Engraftment}

The immunocompetent donor leukocytes in organ transplantation are highly immunogenic multilineage "passenger leukocytes" of bone marrow origin /including stem and dendritic cells) that migrate preferentially to host lymphoid organs and are replaced in the graft by host cells. The result is widespread antigen-specific immune activation of the coexisting donor and recipient cells, each by the other, which proceeds in successful cases to variable reciprocal clonal exhaustion and then deletion (Fig. 79.7).

Engraftment under clinical circumstances requires an umbrella of immunosuppression to prevent one cell population from destroying the other, but in some experimental models it occurs spontaneously (e.g., after pig liver transplantation and in many rodent models). The "nullification" of the two arms explains the poor prognostic value of HLA matching for organ versus bone marrow transplantation (Table 79.6) and the low incidence of GVHD following the engraftment in

FIGURE 79.11. Variable outcomes after infection with widely disseminated noncytopathic viruses (or other microorganisms| and analogies (in the text below the horizon. tal axes) to organ and bone marrow transplantation. Horizontal axis, time; vertical axis, viral load $(v$, solid line and host immune response $(I R$, dashed line).

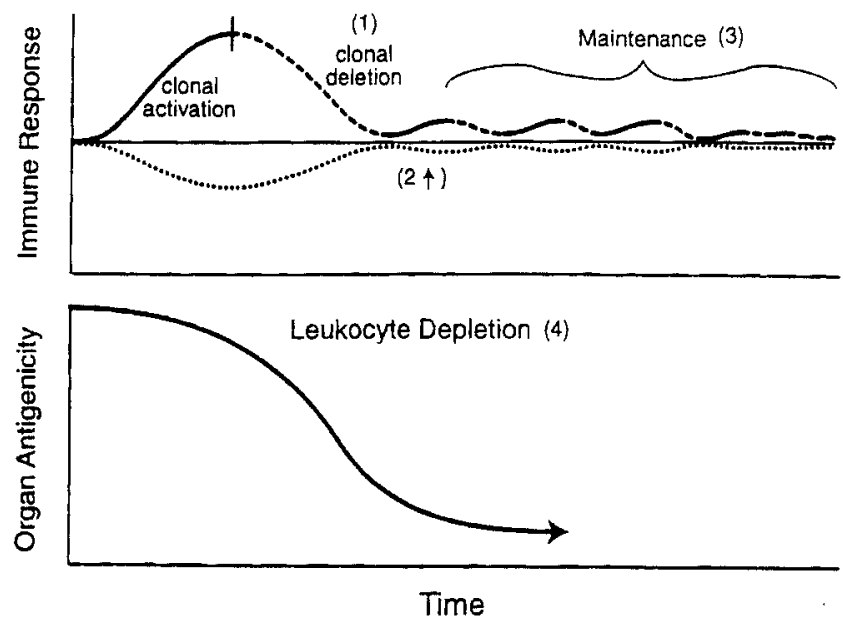

FIGURE 79.10. The four events that occur in close temporal approximation when there is successful organ engraftment. Top, double acute clonal exhaustion $(1,2)$ and subsequent maintenance clonal exhaustion (3) plus (bottom) loss of organ immunogenicity caused by depletion of the graft's passenger leukocytes (4).

noncytoablated recipients of immunologically active organs, such as the intestine and liver.

In addition to inducing clonal activation and exhaustion by trafficking to host lymphoid organs, donor leukocytes that survive the initial destructive immune reaction migrate secondarily to nonlymphoid areas, where they do not generate an immune response ("immune indifference"). From here they may "leak" periodically to the host lymphoid organs and maintain clonal exhaustion. With clonal exhaustion/deletion and immune indifference in combination, both of which are regulated by the migration and localization of the antigen, ${ }^{33}$ the four interrelated events shown schematically in Figure 79.10 must occur close together to have organ engraftment: double acute clonal exhaustion; maintenance clonal exhaustion, which frequently waxes and wanes; and loss of graft immunogenicity as the organ is depleted of its passenger leukocytes.

\section{Bone Marrow Tolerance}

Pretransplant cytoablation renders the recipient susceptible to immune attack by donor immune cells (i.e., GVHD), control of which frequently becomes the principal objective of immunosuppression rather than the prevention of rejection (see Table 79.6). Because complete destruction of host

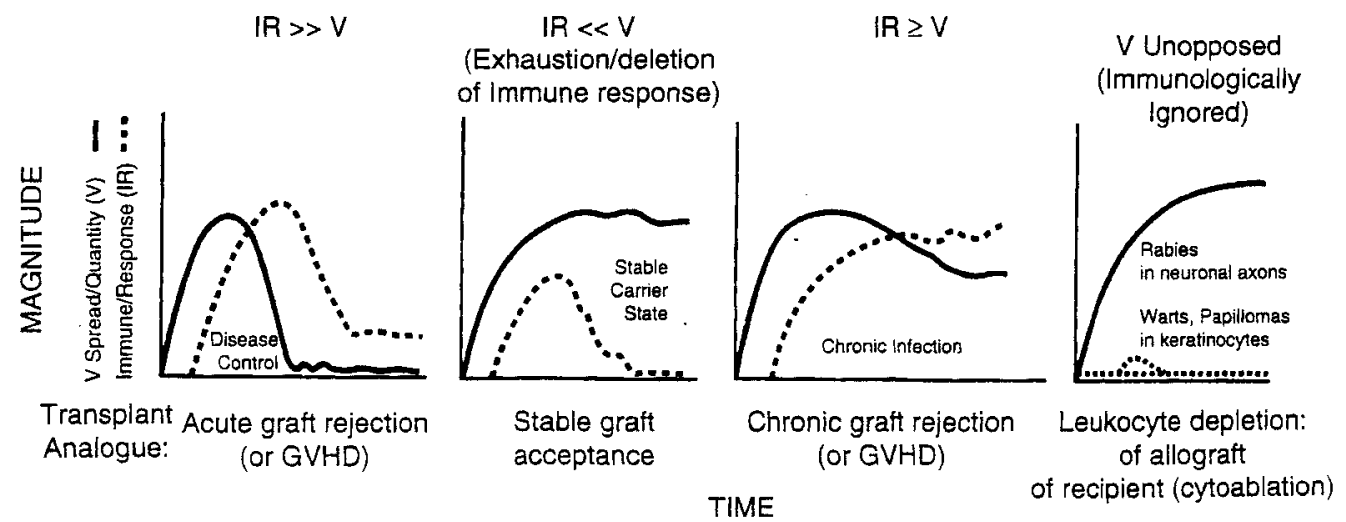


TABLE 79.6. Differences Between Conventional Bone Marrow and Organ Transplantation.

\begin{tabular}{lll}
\hline Bone marrow & & Organ \\
\hline Yes & $\bullet$ Recipient cytoablation" & No \\
Critical & $\bullet$ MHC compatibility• & Not critical \\
GVHD & - Principal complication & Rejection \\
Common & -Drug-free state• & Rare \\
Tolerance & $\leftarrow$ Term for success $\rightarrow$ & "Acceptance"b
\end{tabular}

${ }^{2}$ Note: All differences derive from this therapeutic step, which in effect establishes an unopposed GVH reaction in the bone marrow recipient whose countervailing immune reaction is eliminated.

bor "operational tolerance."

leukocytes is not possible with conventional doses of cytoablation, ${ }^{301}$ the remaining cells will stimulate an alloresponse by mature or maturing donor $\mathrm{T}$ cells. Nevertheless, under immunosuppressive treatment, a weak host-versus-graft reaction mounted by these few recipient cells and a parallel graftversus-host reaction mounted by the donor bone marrow cells may eventually result in reciprocal tolerance by deletion. These processes represent a mirror image of the events after organ transplantation (see Fig. 79.8, bottom right).

\section{Relation to Infectious Disease}

\section{NONCYTOPATHIC MiCROORGANISMS}

Early workers in transplantation ${ }^{302,303}$ recognized the resemblance of allograft rejection to the response against infections associated with delayed hypersensitivity, exemplified by tuberculosis. With the demonstration in 1973 of the MHCrestricted mechanisms of adaptive infectious immunity by Doherty and Zinkernagel, ${ }^{304-307}$ it became obvious that allograft rejection must be the physiological equivalent of the response to this kind of infection. Microorganisms that generate such an adaptive immune response are generally intracellular and have no or low cytopathic qualities. ${ }^{308}$

Although MHC-restricted host cytolytic $\mathrm{T}$ lymphocytes recognize only infected cells, elimination of all the infected cells could disable or even kill the host. Consequently, mechanisms have evolved that can temper or terminate the immune response, allowing both host and pathogen to survive. ${ }^{308,309}$ These are the same two mechanisms that allow survival of allografts (i.e., clonal exhaustion/deletion and immune indifferencel, ${ }^{33}$ both of which are governed by antigen migration and localization..$^{33,308,309}$ However, unlike the complex dual immune response of transplantation, infectious immunity is essentially a host-versus-pathogen reaction.

The analogies between transplantation and an infection with disseminated noncytopathic microorganisms can be exemplified by the common hepatitis viruses, as shown in Figure 79.11. ${ }^{33,308,309}$ The pathogen (antigen) load may rapidly increase during the so-called latent period, but then be dramatically and efficiently controlled by antigen-specific effector $T$ cells, which then subside (left panel). The transplantation analogues are acute irreversible rejection (or intractable GVHD). Alternatively, a continuously high antigen load with an antigen-specific immunological collapse (second panel) is equivalent to unqualified acceptance of an allograft.

Between these two extremes, the persistence of both the infectious agent and a strong immune response result in serious immunopathology (e.g., chronic active hepatitis with $\mathrm{a} B$ or $\mathrm{C}$ virus infection/comparable to chronic rejection after liver transplantation (third panel) or, uncommonly, GVHD. The conditions in the cytoablated bone marrow recipient mimic those of an infection by microorganisms (e.g., rabies and wart viruses/ that avoid immune activation by not migrating through or to host lymphoid organs (right panel). ${ }^{33}$

Because immunity and tolerance to alloantigens follow the same rules as the response to noncy topathic microorganisms, ${ }^{33}$ it is not possible with current transplantation practices to induce tolerance to allografts on the one hand without risking unwanted tolerance to pathogens on the other. In this context, the historical anxiety depicted in Figure 79.4 was correct.

\section{Cytopathic Microorganisms}

There is no MHC-restricted safety valve for cytopathic microorganisms, which are typically extracellular and generate the full resources of the innate as well as the adaptive immune system. ${ }^{308,309}$ An uncontrollable innate immune response involving the effectors shown in Table 79.7 is provoked by discordant xenografts expressing the Gal- $\alpha$-Gal epitope, an epitope that also is found on numerous cytopathic bacteria, protozoa, and viruses.

The clinical use of such discordant animal donors will require changing the xenogeneic epitope to one that mimics a noncytopathic profile or else elimination of the epitope. ${ }^{310}$ Although chimpanzees and baboons do not express the Gal antigen, the clinical xenografts transplanted in 1963 from these subhuman primate donors ${ }^{50,51}$ ultimately were damaged by an uncontrollable innate immune reaction, dominated by complement activation. Similar innate immune mechanisms were recognized in the 1960 s to be responsible for the hyperacute destruction of $\mathrm{ABO}$-incompatible allografts or allografts transplanted to presensitized recipients (see earlier ${ }^{263-268}$ ).

\section{Self-Nonself-Discrimination}

Survival in a hostile environment requires the ability to mount a protective immune response while avoiding a reaction of the immune system against self. Transplantation has succeeded because it has not lethally eroded this capability, which depends ultimately on the governance of immunological responsiveness or unresponsiveness by migration and localization of antigen. ${ }^{33}$ Because the fetus possesses very early T-cell immune function, ${ }^{311-313}$ the ontogeny of self-nonself-discrimination during fetal development can be explained by the same mechanisms as acquired tolerance in

TABLE 79.7. Effectors Involved in Response to Cytopathic Parasites and Discordant Xenografts.

\footnotetext{
The first line of defense

Interferons

Macrophages

Gamma/delta $T$ cells

Natural killer (NK) cells

$\mathrm{B}$ cells

Nonspecific or less-specific effectors

Complement

Early interleukins

Phagocytes
} 
later life. Autoimmune diseases then reflect unacceptable postnatal perturbations of the prenatally established localization of self-antigens in nonlymphoid versus lymphoid compartments. ${ }^{33}$

\section{Conclusion}

The lesson described in this chapter has been leamed many times before: All knowledge can be traced to its roots and ultimately to a seed. For clinical transplantation, the historical beginning was Medawar's recognition that rejection is an immune reaction. Only two primary roots sprang from this seed. One was the demonstration by Billingham, Brent, and Medawar in 1953 that tolerance could be acquired by producing stem cell-driven hematolymphopoietic chimerism ${ }^{5}$; this concept ultimately led to bone marrow transplantation in humans.

The other root was the demonstration during 1962-1963 that kidney allografts could consistently self-induce tolerance with the aid of immunosuppression ${ }^{30}$; all further developments in organ transplantation were derivative from this discovery. The assumption reached by consensus in the early 1960 s that the two roots reflected different immune mechanisms led to inadequate explanations of organ allograft acceptance and clouded the meaning of successful bone marrow transplantation.

The false assumption, which promptly became dogma, saddled succeeding generations of scientists and clinicians with a context that precluded the synthesis of a clarifying central principle of immunology that could be applied to all transplant, much less nontransplant, circumstances. After it was discovered in 1992 that organ recipients had persistent microchimerism, it was possible to see the essential commonality of organ and bone marrow transplantation, to relate observations after these procedures to the immune response to infectious diseases and neoplasms, and to explain the genesis of self-nonself-discrimination.

\section{Epilogue}

This chapter was originally prepared between August 1997 and August 1998. The immunologic paradigm that had emerged by then ${ }^{31-34,106,287-293}$ was finalized in two collaborative reviews with RolfZinkernagel (Nobel Laureate, 1996)..$^{314,315}$ It proved difficult to explain the new concept to persons whose career development for legacy) during the preceding third of a century depended on not understanding it. The bitter pill that had to be swallowed was the reality that almost all of the clinical and experimental observations in transplantation immunology, and particularly those involved with organ engraftment, had been inserted from 1962 onward into an invalid intellectual framework. The consequence of the error was an epistemologic collapse, that is, a failure to understand. ${ }^{316}$ As for the new paradigm, no modifications of the chapter written in 1997-1998 have been necessary. Moreover, the fresh insight into immunoregulation has been systematically exploited for therapeutic purposes under numerous transplant- and nontransplant-related circumstances. ${ }^{317-319}$ Thus, both the old and new history of transplantation is a work in progress.

\section{References}

1. Terasaki PI, ed. History of HLA: Ten Recollections. Los Angeles: UCLA Tissue Typing Laboratory; 1990:1-269.

2. Terasaki PI, ed. History of Transplantation: Thirty-Five Recollections. Los Angeles: UCLA Tissue Typing Laboratory; 1990:1704.

3. Gibson T, Medawar PB. The fate of skin homografts in man. J Anat 1943;77:299-310.

4. Medawar PB. The behavior and fate of skin autografts and skin homografts in rabbits. J Anat 1944;78:176-199.

5. Billingham RE, Brent L, Medawar PB. "Actively acquired tolerance" of foreign cells. Nature 1953;172:603-606

6. Traub E. Persistence of lymphocytic choriomeningitis virus in immune animals and its relation to immunity. J Exp Med $1936 ; 63: 847-861$.

7. Murphy JB. Transplantability of malignant tumors to the embryos of a foreign species. JAMA 1912;59:874-875.

8. Murphy JB. Factors of resistance to heteroplastic tissuegraftings: studies in tissue specificity. J Exp Med 1914;19:513522.

9. Billingham R, Brent L, Medawar P. Quantitative studies on tissue transplantation inmunity: actively acquired tolerance. Philos Trans R Soc Lond B Biol Sci 1956;239:357-412.

10. Hasek M. Vegetavni hybridisace zivocichu spojenim krevnich obehu v embryonainim vyvojhi. Cesk Biol 1953;2:265.

11. Owen RD. Immunogenetic consequences of vascular anastomo. ses between bovine twins. Science 1945;102:400-401.

12. Anderson D, Billingham RE, Lampkin GH, Medawar PB. The use of skin grafting to distinguish between monozygotic and dizygotic twins in cattle. Heredity 1951;5:379-397.

13. Bumet FM, Fenner F. The Production of Antibodies. 2nd ed. Melboume: Macmillan; 1949:1-142.

14. Billingham $R$, Brent $L$. A simple method for inducing tolerance of skin homografts in mice. Trans Bull 1957;4:67-71.

15. Billingham R, Brent $L$. Quantitative studies on transplantation immunity: induction of tolerance in newborn mice and studies on the phenomenon of runt disease. Philos Trans R Soc Lond B Biol Sci $1959 ; 242: 439-477$.

16. Simonsen $M$. The impact on the developing embryo and newbom animal of adult homologous cells. APMIS 1957,40:480-500.

17. Brent L. A History of Transplantation Immunology. London: Academic Press; 1997:1-482.

18. Merrill JP, Murray JE, Harrison JH, Friedman EA, Dealy JB Jr, Dammin GI. Successful homotransplantation of the kidney between non-identical twins. N Engl J Med 1960;262:1251-1260.

19. Starzl TE, Groth CG, Brettschneider L, et al. Orthotopic homotransplantation of the human liver. Ann Surg 1968;168:392415.

20. Barnard $C N$. What we have learned about heart transplants. J Thorac Cardiovasc Surg 1968;56:457-468.

21. Dong E as told by Shumway NE and Lower RR. In: Terasaki PI, ed. History of Transplantation: Thirty-Five Recollections. Los Angeles: UCLA Tissue Typing Laboratory; 1991:435-449.

22. Derom F, Barbier F, Ringoir $S$, et al. Ten-month survival after lung homotransplantation in man. J Thorac Cardiovasc Surg $1971 ; 61: 835-846$.

23. Lillehei RC, Simmons RL, Najarian IS, et al. Pancreaticoduodenal allotransplantation: experimental and clinical observations. Ann Surg 1970;172:405-436.

24. Goulet O, Revillon $Y$, Brousse $N$, et al. Successful small bowel transplantation in an infant. Transplantation (Baltimore) 1992; 53:940-943.

25. Starzl TE, Rowe $M$, Todo $S$, et al. Transplantation of multiple abdominal viscera. JAMA 1989;261:1449-1457.

26. Mathe G, Amiel JL, Schwarzenberg L, Cattan A, Schneider M. Haematopoietic chimera in man after allogenic (homologous) bone-marrow transplantation. Br Med I 1963;2:1633-1635. 
27. Bach FH. Bone-marrow transplantation in a patient with the Wiskott-Aldrich syndrome. Lancet $1968 ; 2: 1364-1366$.

28. Gatti RA, Meuwissen HI, Allen HD, Hong R, Good RA. Immunological reconstitution of sex-linked lymphopenic immunological deficiency. Lancet 1968;2:1366-1369.

29. Thomas ED. Allogeneic marrow grafting: a story of man and dog. In: Terasaki PI, ed. History of Transplantation: Thirty-Five Recollections. Los Angeles: UCLA Tissue Typing Laboratory; 1991:379-393.

30. Starzl TE, Marchioro TL, Waddell WR. The reversal of rejection in human renal homografts with subsequent development of homograft tolerance. Surg Gynecol Obstet 1963;117:385395.

31. Starzl TE, Demetris AJ, Murase N, Ildstad S, Ricordi C, Trucco $M$. Cell migration, chimerism, and graft acceptance. Lancet 1992;339:1579-1582.

32. Starzl TE, Demetris AI, Trucco $M$, et al. Cell migration and chimerism after whole-organ transplantation: the basis of graft acceptance. Hepatology 1993;17:1127-1152.

33. Starzl TE, Zinkernagel RM. Antigen localization and migration in immunity and tolerance. $N$ Engl J Med 1998;339:1905-1913.

34. Starzl TE, Demetris AJ. Transplantation milestones: viewed with one- and two-way paradigms of tolerance. JAMA 1995;273: 876-879.

35. Carrel $\mathrm{A}$. The operative technique for vascular anastomoses and transplantation of viscera. Lyon Med 1902;98:859.

36. Woodruff MFA. The Transplantation of Tissues and Organs. Springfield, Il: Thomas; 1960:1-777.

37. Simonsen M, Buemann I, Gammeltoft A, et al. Biological incompatibility in kidney transplantation in dogs: experimental and morphological investigations. APMIS 1953;32:36-84.

38. Moore FD, Smith LL, Burnap TK, et al. One-stage homotransplantation of the liver following total hepatectomy in dogs. Transplant Bull 1959;6:103-110.

39. Dempster WT. Kidney homotransplantation. Br J Surg 1953;40: $447-465$.

40. Lillehei RC, Goott B, Miller FB. The physiologic response of the small bowel of the dog to ischemia including prolonged in vitro preservation of the bowel with successful replacement and survival. Ann Surg 1959;150:543-560.

41. Moore FD, Wheeler HB, Demissianos HV, et al. Experimental whole organ transplantation of the liver and of the spleen. Ann Surg 1960;152:374-387.

42. Starzl TE, Kaupp HA Ir, Brock DR, Lazarus RE, Johnson RV. Reconstructive problems in canine liver homotransplantation with special reference to the postoperative role of hepatic venous flow. Surg Gynecol Obstet 1960;111:733-743.

43. Starzl TE, Kaupp HA Ir. Mass homotransplantation of abdominal organs in dogs. Surg Forum 1960; 11:28-30.

44. Lower RR, Shumway NE. Studies on orthotopic homotransplantation of the canine heart. Surg Fonum 1960;11:18.

45. Lower RR, Stofer RC, Shumway NE. Homovital transplantation of the heart. J Thorac Cardiovasc Surg 1961;41:196-204.

46. Lower RR, Stofer RC, Hurley EJ, Shumway NE. Complete homograft replacement of the heart and both lungs. Surgery 1961;50: 842-845.

47. Jaboulay M. Greffe du reins au pli du coude par soudures arterielles et veineuses [Kidney grafts in the antecubital fossa by arterial and venous anastomosis]. Lyon Med 1906;107:575-577.

48. Unger E. Nierentransplantation [Kidney transplantation]. Wien Klin Wochenschr 1910;47:573-578.

49. Groth CG. Landmarks in clinical renal transplantation. Surg Gynecol Obstet 1972;134:323-328.

50. Reemstsma K, McCracken BH, Schlegel JU, et al. Renal heterotransplantation in man. Ann Surg 1964;160:384-410.

51. Starzl TE, Marchioro TL, Peters GN, et ai. Renal heterotransplantation from baboon to man: experience with six cases. Transplantation 1964;2:752-776.
52. Voronoy U. Sobre bloqueo del aparato reticuloendotelial del hombre en algunas formas de intoxicacion por el sublimado y sobre la transplantacion del rinon cadaverico como metodo de tratamiento de la anuria consecutiva a aquella intoxica. cion [Blocking the reticuloendothelial system in man in some forms of mercuric chloride intoxication and the transplanta. tion of the cadaver kidney as a method of treatment for the anuria resulting from the intoxication]. Siglo Med 1937;97:296297.

53. Starzl TE. Patterns of permissible donor-recipient tissue transfer in relation to $\mathrm{ABO}$ blood groups. In: Experience in Renal Transplantation. Philadelphia: Saunders; 1964:37-47.

54. Ramsey G, Nusbacher I, Starzl TE, Lindsay GD. Isohemagglutinins of grafts origin after $\mathrm{ABO}$-unmatched liver transplantation. N Engl J Med 1984;311:1167-1170.

55. Hamilton DNH, Reid WA. U Voronoy and the first human kidney allograft. Surg Gynecol Obstet 1984;159:289-294.

56. Kuss R, Teinturier I, Milliez P. Quelques essais de greffe rein chez l'homme. Mem Acad Chir 1951;77:755-764.

57. Dubost C, Oeconomos N, Nenna A, Milliez P. Resultats d'une tentative de greffe renale. Bull Soc Med Hop Paris 1951;67:13721382.

58. Servelle M, Soulie P, Rougeulle J. Greffe d'une rein de supplicie a une malade avec rein unique congenital, atteinte de nephrite chronique hypertensive azatemique. Bull Soc Med Hop Paris 1951;67:99-104.

59. Michon L, Hamburger J, Oeconomos N, et al. Une tentative de transplantation renale chez l'homme: aspects medicaux et biologiques. Presse Med 1953;61:1419-1423.

60. Merrill JP, Murray JE, Harrison JH, Guild WR. Successful homotransplantation of the human kidney between identical twins. JAMA 1956;160:277-282.

61. Hume DM, Merrill JP, Miller BF, Thorn GW. Experiences with renal homotransplantation in the human: report of nine cases. J Clin Invest 1955;34:327-382.

62. Moore FD. The development of tissue transplantation. In: Give and Take. Philadelphia: Saunders; 1964:1-182.

63. Billingham RE, Krohn PL, Medawar PB. Effect of cortisone on survival of skin homografts in rabbits. Br Med J 1951;1:11571163.

64. Morgan JA. The influence of cortisone on the survival of homografts of skin in the rabbit. Surgery (St. Louis) 1951;30:506515.

65. Cannon JA, Longmire WP. Studies of successful skin homografts in the chicken. Ann Surg 1952;135:60-68.

66. Krohn PL. Effect of cortisone on second set skin homografts in rabbits. Br J Exp Pathol 1954;35:539.

67. Lawler RH, West JW, McNulty PH, Clancy EJ, Murphy RP. Homotransplantation of the kidney in the human. JAMA $1950 ; 144: 844-845$.

68. Murray G, Holden R. Transplantation of kidneys, experimentally and in human cases. Am I Surg 1954;87:508519.

69. Murray JE, Merrill JP, Harrison JH. Renal homotransplantation in identical twins. Surg Forum 1955;6:432-436.

70. Brown JB. Homografting of skin: with report of success in identical twins. Surgery $1937 ; 1: 558-563$.

71. Nossal GJV. Antibody production of single cells. Nature 1958; 181:1419-1420.

72. Dempster WT, Lennox B, Boag JW. Prolongation of survival of skin homotransplants in the rabbit by irradiation of the host. $\mathrm{Br}$ J Exp Pathol 1950;31:670-679.

73. Cannon JA, Terasaki P, Longmire WP. Studies of factors influencing induced tolerance to skin homografts in the chicken. Ann Surg 1957;146:278-284.

74. Main IM, Prehn RT. Successful skin homografts after the administration of high dosage $\mathrm{X}$ radiation and homologous bone marrow. J Natl Cancer Inst 1955;15:1023-1029. 
75. Trentin J. Mortality and skin transplantibility in X-irradiated mice receiving isologous or heterologous bone marrow. Proc Soc Exp Biol Med 1956;92:688-693.

76. Mannick JA, Lochte HL, Ashley CA, Thomas ED, Ferrebee JW A functioning kidney homotransplant in the dog. Surgery 1959; 46:821-828.

77. Storb R, Epstein RB, Bryant J, Ragde H, Thomas ED. Marrow grafts by combined marrow and leukocyte infusions in unrelated dogs selected by histocompatibility typing. Transplantation $1968 ; 6: 587-593$

78. Epstein RB, Storb R, Ragde H, Thomas ED. Cytotoxic typing antisera for marrow grafting in litter mate dogs. Transplantation $1968 ; 6: 45-58$.

79. Hume DM, Jackson BT, Zukoski CF, Lee HM, Kauffman HM, Egdahl RH. The homotransplantation of kidneys and of fetal liver and spleen after total body irradiation. Ann Surg 1960; 152:354-373.

80. Rapaport FT, Bachvaroff RJ, Mollen N, Hirasawa $H$, Asano $T$, Ferrebee $\mathrm{TW}$. Induction of unresponsiveness to major transplantable organs in adult mammals. Ann Surg 1979;190:461-473.

81. van Bekkum DW. Bone marrow transplantation: a story of stem cells. In: Terasaki PI, ed. History of Transplantation: Thirty-Five Recollections. Los Angeles: UCLA Tissue Typing Laboratory; 1991:395-434.

82. Murray JE, Merrill JP, Dammin GJ, et al. Study of transplantation immunity after total body irradiation: clinical and experimental investigation. Surgery 1960;48:272-284.

83. Murray JE, Merrill TP, Dammin GJ, Dealy JB Jr, Alexandre GW, Harrison $\mathrm{H}$. Kidney transplantation in modified recipients. Ann Surg 1962;156:337-355.

84. Hamburger I, Vaysse J, Crosnier J, et al. Transplantation of a kidney between nonmonozygotic twins after irradiation of the receiver: good function at the fourth month. Presse Med 1959; 67:1771-1775.

85. Hamburger I, Vaysse J, Crosnier J, Auvert I, Lalanne CL, Hopper I Jr. Renal homotransplantation in man after radiation of the recipient. Am J Med 1962;32:854-871.

86. Kuss R, Legrain M, Mathe G, Nedey R, Camey $M$. Homologous human kidney transplantation: experience with six patients. Postgrad Med J 1962;38:528-531.

87. Kuss R. Human renal transplantation memories, 1951 to 1981. In: Terasaki PI, ed. History of Transplantation: Thirty-Five Recollections. Los Angeles: UCLA Tissue Typing Laboratory; 1991.

88. Murray JE. Nobel Prize lecture: the first successful organ transplants in man. In: Terasaki PI, ed. History of Transplantation: Thirty-Five Recollections. Los Angeles: UCLA Tissue Typing Laboratory; 1991:121-143.

89. Goodwin WE, Kaufman J, Mims MM, et al. Human renal transplantation: clinical experience with six cases of renal homotransplantation. J Urology 1963;89:13-24.

90. Schwartz R, Dameshek W. Drug-induced immunological tolerance. Nature 1959;183:1682-1683.

91. Schwartz R, Dameshek W. The effects of 6-mercaptopurine on homograft reactions. J Clin Invest 1960;39:952-958.

92. Meeker W, Condie R, Weiner D, Varco RL, Good RA. Prolongation of skin homograft survival in rabbits by 6-mercaptopurine. Proc Soc Exp Biol Med 1959;102:459-461.

93. Calne RY. The rejection of renal homografts: inhibition in dogs by 6-mercaptopurine. Lancet $1960 ; 1: 417-418$.

94. Zukoski CF, Lee HM, Hume DM. The prolongation of functional survival of canine renal homografts by 6-mercaptopurine. Surg Forum 1960;1 1:470-472.

95. Calne RY. Inhibition of the rejection of renal homografts in dogs by purine analogues. Transplant Bull 1961;28:445-461.

96. Calne RY, Murray IE. Inhibition of the rejection of renal homografts in dogs by Burroughs Wellcome 57-222. Surg Forum $1961 ; 12: 118-120$.
97. Calne RY, Alexandre GPI, Murray JE. A study of the effects of drugs in prolonging survival of homologous renal transplants in dogs. Ann N Y Acad Sci 1962;99:743-761.

98. Hitchings GH, Elion GB. The chemistry and biochemistry of purine analogs. Ann N Y Acad Sci 1954;60:195.

99. Pierce JC, Varco RL. Induction of tolerance to a canine renal homotransplant with 6-mercaptopurine. Lancet 1962;1:781782.

100. Zukoski CF, Callaway JM. Adult tolerance induced by 6-methyl mercaptopurine to canine renal homografts. Nature 1963;198:706707.

101. Starzl TE. Host-graft adaptation. In: Experience in Renal Transplantation. Philadelphia: Saunders; 1964:164-170.

102. Murray JE, Sheil AGR, Moseley R, Knoght PR, McGavic ID, Dammin G). Analysis of mechanism of immunosuppressive drugs in renal homotransplantation. Ann Surg 1964;160:449473.

103. Hopewell J, Calne RY, Beswick I. Three clinical cases of renal transplantation. Br Med J 1964;I:411-413.

104. Alexandre GPI, Murray JE. Further studies of renal homotransplantation in dogs treated by combined Imuran therapy. Surg Forum 1962;13:64-66.

105. Murray JE, Merrill JP, Harrison JH, Wilson RE, Dammin GJ. Prolonged survival of human-kidney homografts by immunosuppressive drug therapy. N Engl J Med 1963;268:1315-1323.

106. Starzl TE, Demetris AJ, Murase N, Trucco M, Thomson AW, Rao AS. The lost chord: microchimerism. Immunol Today 1996; 17:577-584.

107. Hume DM, Magee JH, Kauffman HM Jr, Rittenbury MS, Prout GR Jr. Renal homotransplantation in man in modified recipients. Ann Surg 1963;158:608-644.

108. Woodruff MFA, Robson IS, Nolan B, Lambie AT, Wilson TI, Clark JG. Homotransplantation of kidney in patients treated by preoperative local radiation and postoperative administration of an antimetabolite (Imuran). Lancet 1963:2:675-682.

109. Medawar PB. Transplantation of tissues and organs: introduction. Br Med Bull 1965;21:97-99.

110. Woodruff MFA, Woodruff HG. The transplantation of normal tissues: with special reference to auto- and homotransplants of thyroid and spleen in the anterior chamber of the eye, and subcutaneously, in guinea pigs. Phil Trans B 1950;234:559-581.

111. Woodruff MFA. Evidence of adaptation in homografts of normal tissue. In: Medawar PB, ed. Biological Problems of Grafting. Oxford: Blackwell Scientific; 1959:83-94.

112. Starzl TE. Precepts of renal homotransplantation applied to homografting of other organs. In: Experience in Renal Transplantation. Philadelphia: Saunders; 1964:360-362.

113. Starzl TE, Kaupp HA Jr, Brock DR, Butz GW Jr, Linman JW. Homotransplantation of multiple visceral organs. Am I Surg $1962 ; 103: 219-229$

114. Murase N, Demetris AJ, Kim DG, Todo S, Fung II, Starzl TE. Rejection of the multivisceral allografts in rats: a sequential analysis with comparison to isolated orthotopic small bowel and liver grafts. Surgery 1990;108:880-889.

115. Murase N, Demetris AJ, Matsuzaki T, et al. Long survival in rats after multivisceral versus isolated small bowel allotransplantation under FK 506. Surgery 1991;110:87-98.

116. Starzl TE, Marchioro TL, Porter KA, et al. Factors determining short- and long-term survival after orthotopic liver homotransplantation in the dog. Surgery 1965;58:131-155.

117. Starzl TE. Efforts to mitigate or prevent rejection. In: Experience in Hepatic Transplantation. Philadelphia: Saunders; 1969:203206.

118. Cordier G, Garnier H, Clot JP, et al. La greffe de foie orthotopique chez le porc. Mem Acad Chir (Paris) 1966;92:799-807.

119. Peacock $\pi \mathrm{H}$, Terblanche J. Orthotopic homotransplantation of the liver in the pig. In: Read $A E$, ed. The Liver. London: Butterworth; 1967:333. 
120. Calne RY, White HJO, Yoffa DE, et al. Observations of orthotopic liver transplantation in the pig. Br Med J 1967;2:478-480.

121. Calne RY, White HJO, Yoffa DE, et al. Prolonged survival of liver transplants in the pig. Br Med J 1967;4:645-648.

122. Starzl TE. Rejection in unmodified animals. In: Experience in Hepatic Transplantation. Philadelphia: Saunders; 1969:184.

123. Hunt AC. Pathology of liver transplantation in the pig. In: Read $\mathrm{AE}$, ed. The Liver. London: Butterworth; 1967:337.

124. Porter KA. Pathology of the orthotopic homograft and heterograft. In: Starzl TE, ed. Experience in Hepatic Transplantation. Philadelphia: Saunders; 1969:427.

125. Calne RY, Sells RA, Pena Jr, et al. Induction of immunological tolerance by porcine liver allografts. Nature 1969;223:472-474.

126. Zimmerman FA, Davies HS, Knoll PP, Gocke JM, Schmidt T. Orthotopic liver allografts in the rat. Transplantation 1984;37: $406-410$.

127. Kamada N, Brons G, Davies $H$. Fully allogeneic liver grafting in rats induces a state of systemic nonreactivity to donor transplantation antigens. Transplantation 1980;29:429-431.

128. Kamada N, Davies HS, Roser B. Reversal of transplantation immunity by liver grafting. Nature $1981 ; 292: 840-842$.

129. Corry RJ, Winn HJ, Russell PS. Primary vascularized allografts of hearts in mice: the role of $\mathrm{H}-2 \mathrm{D}, \mathrm{H}-2 \mathrm{~K}$, and non- $\mathrm{H}-2$ antigens in rejection. Transplantation $1973 ; 16: 343-350$.

130. Russell PS, Chase CM, Colvin RB, Plate JMD. Kidney transplants in mice: an analysis of the immune status of mice bearing long-term H-2 incompatible transplants. J Exp Med 1978;147: 1449-1468.

131. Starzl TE. Host graft adaptation. In: Experience in Renal Transplantation. Philadelphia: Saunders; 1964:168-170.

132. Starzl TE. Efforts to mitigate or prevent rejection. In: Experience in Hepatic Transplantation. Philadelphia: Saunders; 1969:228233.

133. Steinman RM, Cohn ZA. Identification of a novel cell type in peripheral lymphoid organs of mice: morphology, quantitation, tissue distribution. I Exp Med 1973;137:1142-1162.

134. Simonsen $M$. On the acquisition of tolerance by adult cells. Ann N Y Acad Sci 1960;87:382-390.

135. Bumet FM. The Clonal Selection Theory of Acquired Immunity. Nashville: Vanderbilt University Press; 1959:59.

136. Talmage DW. Immunological specificity. Science 1959;129:1649_ 1653.

137. Bumet FM. The new approach to immunology. N Engl J Med $1961 ; 264: 24-34$.

138. Miller IFAP. Immunological function of the thymus. Lancet $1961 ; 2: 748-749$.

139. Miller JFAP. Effect of neonatal thymectomy on the immunological responsiveness of the mouse. Proc R Soc Lond Biol Sci $1962 ; 156: 415$.

140. Starzl TE, Marchioro TL, Talmage DW, Waddell WR. Splenectomy and thymectomy in human renal homotransplantation. Proc Soc Exp Biol Med 1963;113:929-932.

141. Starzl TE, Porter KA, Andres G, et al. Thymectomy and renal homotransplantation. Clin Exp Immunol 1970;6:803-814.

142. McGregor DD, Gowans IL. Antibody response of rats depleted of lymphocytes by chronic drainage from the thoracic duct. J Exp Med 1963;117:303-320.

143. McGregor DD, Gowans JL. Survival of homografts of skin in rats depleted of lymphocytes by chronic drainage from the thoracic duct. Lancet $1964 ; 1: 629-632$.

144. Algire GH, Weaver JM, Prehn RT. Studies on tissue homotransplantation in mice using diffusion chamber methods. Ann N.Y Acad Sci 1957;64:1009.

145. Starzl TE, Kaupp HA Jr, Brock DR, Linman JW. Studies on the rejection of the transplanted homologous dog liver. Surg Gynecol Obstet 1961;112:135-144.

146. Starzl TE, Butz GW Jr. Surgical physiology of the transplantation of tissues and organs. Surg Clin North Am 1962;42:55-67.
147. Elkinton JR. Moral problems in the use of borrowed organs, artificial and transplanted. Ann Intern Med 1964;60:309313.

148. Starzl TE, Marchioro TL, Rifkind D, Holmes $\Gamma$, Rowlands DT Ir, Waddell WR. Factors in successful renal transplantation. Surgery 1964;56:296-318.

149. Rifkind D. Infectious diseases associated with renal transplanta-

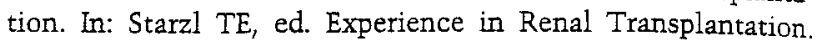
Philadelphia: Saunders; 1964:213-238.

150. Starzl TE. Discussion of Murray JE, Wilson RE, Tilney NL, Merrill JP, Cooper WC, Birtch $\mathrm{AG}_{\text {, }}$ Carpenter $\mathrm{CB}$, Hager $\mathrm{EB}$, Dammin G], Harrison $H$ : 5 years experience in renal transplantation with immunosuppressive drugs. Ann Surg 1968;168:416435.

151. Penn I, Hammond W, Brettschneider L, Starzl TE. Malignant lymphomas in transplantation patients. Transplant Proc $1969 ; 1: 106-112$.

152. Starzl TE, Penn I, Putnam CW, Groth CG, Halgrimson CG. Iatrogenic alterations of immunologic surveillance in man and their influence on malignancy. Transplant Rev 1971;7:112145.

153. Hill RB Jr, Rowlands DT, Rifkind D. Infectious pulmonary disease in patients receiving immunosuppressive therapy for organ transplantation. N Engl J Med 1964;271:1021-1C27.

154. Rifkind D, Starzl TE, Marchioro TL, Waddell WR, Rowlands DT Jr, Hill RB Jr. Transplantation pneumonia. JAMA 1964;189:808812.

155. Iwasaki Y, Porter KA, Amend JR, Marchioro TL, Zuhlke V, Starzl TE. The preparation and testing of horse antidog and antihuman antilymphoid plasma or serum and its protein fractions. Surg Gynecol Obstet 1967;124:1-24.

156. Starzl TE, Marchioro TL, Porter KA, Iwasaki Y, Cerilli G. The use of heterologous antilymphoid agents in canine renal and liver homotransplantation and in human renal homotransplantation. Surg Gynecol Obstet 1967;124:301-318.

157. Woodruff MFA, Anderson NF. Effect of lymphocyte depletion by thoracic duct fistula and administration of anti-lymphocytic serum on the survival of skin homografts in rats. Nature 1963;200:702.

158. Franksson C, Blomstrand R. Drainage of the thoracic lymph duct during homologous kidney transplantation in man. Scand J Urol Nephrol 1967;1:123-131.

159. Starzl TE, Weil R II, Koep LJ, Iwaki Y, Terasaki PI, Schroter GPJ. Thoracic duct drainage before and after cadaveric kidney transplantation. Surg Gynecol Obstet 1979;149:815-821.

160. Starzl TE, Klintmalm GBG, Iwatsuki S, Schroter G, Weil R III. Late follow-up after thoracic duct drainage in cadaveric renal transplantation. Surg Gynecol Obstet 1981;153:377382.

161. Slavin S, Reitz B, Bieber CP, Kaplan HS, Strober S. Transplantation tolerance in adult rats using total lymphoid irradiation (TLI): permanent survival of skin, heart, and marrow allografts. I Exp Med 1978;147:700-707.

162. Najarian IS, Ferguson RM, Sutherland DER, et al. Fractionated total lymphoid irradiation as preparative immunosuppression in high-risk renal transplantation. Ann Surg 1982;196:442-452.

163. Myburgh AI, Smit AI, Meyers MA, Botha JR, Browde S, Thomson PD. Total lymphoid irradiation in renal transplantation. World I Surg 1986;10:369-380.

164. Metchnikoff I. Etude sur la resorption des cellules. Ann Inst Pasteur 1899;13:737.

165. Inderbitzen $T$. Histamine in allergic responses of the skin. In: Shafer TH, LeGrippo GA, Chase MW, eds. Henry Ford Hospital International Symposium on Mechanisms of Hypersensitivity, Boston: Little, Brown and Co.; 1959:493-499.

166. Waksman BY, Arbouys S, Amason BG. The use of specific "lymphocyte" antisera to inhibit hypersensitive reactions of the "delayed" type. J Exp Med 1961;114:997-1022. 
167. Levey RH, Medawar PB. Nature and mode of action of antilymphocytic antiserum. Proc Natl Acad Sci U S A 1966;56:11301137.

168. Monaco AP, Wood ML, Russell PS. Adult thymectomy: effect on recovery from immunologic depression in mice. Science $1965 ; 149: 432-435$.

169. Monaco AP, Wood ML, Russell PS. Studies of heterologous antilymphocyte serum in mice: immunologic tolerance and chimerism produced across the $\mathrm{H}-2$ locus with adult thymectomy and antilymphocyte serum. Ann N Y Acad Sci 1966;129:190209.

170. Najarian JS, Simmons RL, Gewurz H, Moberg A, Merkel F, Moore GA. Anti-serum to cultured human lymphoblasts: preparation, purification and immunosuppressive properties in man. Ann Surg 1969;170:617-632.

171. Kohler G, Milstein C. Continuous culture of fused cells secreting antibody of predefined specificity. Nature 1975;256:495497.

172. Cosimi $A B$, Colvin $R B$, Burton $R C$, et al. Use of monoclonal antibodies to $T$-cell subsets for immunological monitoring and treatment in recipients of renal allografts. N Engl J Med 1981; 305:308-314.

173. Starzl TE, Putnam CW, Halgrimson CG, et al. Cyclophosphamide and whole organ transplantation in human beings. Surg Gynecol Obstet 1971;133:981-991.

174. Starzl TE, Groth CG, Putnam CW, et al. Cyclophosphamide for clinical renal and hepatic transplantation. Transplant Proc 1973;5:511-516.

175. Dreyfuss M, Harri E, Hofmann H, Kobel H, Pache W, Tscherter H. Cyclosporin A and C: new metabolites from Trichoderma polysporum (Link ex Pers) Rifai. Eur J Appl Microbiol 1976;3:125133.

176. Ruegger A, Kuhn $M$, Lichti $H$, et al. Cyclosporin A, ein immunosuppressiv wirksamer Peptidmetabolit aus Trichoderma polysporum (Link ex Pers) Rifai. Helv Chim Acta 1976;59:10751092.

177. Petcher TI, Weber HP, Ruegger A. Crystal and molecular structure of an iodo-derivative of the cyclic undercepeptide cyclosporin A. Helv Chim Acta 1976;59:1480-1489.

178. Borel IF. Comparative study of in vitro and in vivo drug effects on cell-mediated cytoxicity. Immunology 1976,31:631-641.

179. Borel JF, Feurer C, Gubler HU, Stahelin H. Biological effects of cyclosporin A: a new antilymphocytic agent. Agents Actions $1976 ; 6: 468-475$.

180. Borel JF, Feurer C, Magnee C, Stahelin H. Effects of the new anti-lymphocytic peptide cyclosporin $A$ in animals. Immunology 1977;32:1017-1025.

181. Kostakis AJ, White DJG, Calne RY. Prolongation of rat heart allograft survival by cyclosporin A. Int Res Commun SystMed Sci 1977;5:280.

182. Calne RY, White DIG. Cyclosporin A: a powerful immunosuppressant in dogs with renal allografts. Int Res Commun Syst Med Sci 1977;5:595

183. Calne RY, White DIG, Rolles K, Smith DP, Herbertson BM. Prolonged survival of pig orthotopic heart grafts treated with cyclosporin A. Lancet 1978;1:1183-1185.

184. Calne RY, White DJG, Pentlow BD, et al. Cyclosporin A: preliminary observations in dogs with pancreatic duodenal allografts and patients with cadaveric renal transplants. Transplant Proc $1979 ; 11: 860-864$

185. Green CJ, Allison AC. Extensive prolongation of rabbit kidney allograft survival after short-term cyclosporin A treatment. Lancet $1978 ; 1: 1182-1183$.

186. Calne RY, White DJG, Thin S, et al. Cyclosporin A in patients receiving renal allografts from cadaver donors. Lancet 1978; 2:1323-1327.

187. Calne RY, Rolles $\mathrm{K}$, White DJG et al. Cyclosporin A initially as the only immunosuppressant in 34 recipients of cadaveric organs: 32 kidneys, 2 pancreases, and 2 livers. Lancet $1979 ; 2: 1033$ 1036.

188. Starzl TE, Weil R III, Iwatsuki S, et al. The use of cyclosporin A and prednisone in cadaver kidney transplantation. Surg Gynecol Obstet 1980;151:17-26.

189. Starzl TE, Klintmalm GBG, Porter KA, Iwatsuki S, Schroter GPI. Liver transplantation with use of cyclosporin $A$ and prednisone. N Engl J Med 1981;305:266-269.

190. Reitz BA, Wallwork JL, Hunt SA, et al. Heart-lung transplantation: successful therapy for patients with pulmonary vascular disease. N Engl T Med 1982;306:557-564.

191. Griffith BP, Hardesty RL, Deeb GM, Starzl TE, Bahnson HT. Cardiac transplantation with cyclosporin $\mathrm{A}$ and prednisone. Ann Surg 1982;196:324-329.

192. Cooper J. The evolution of techniques and indications for lung transplantation. Ann Surg 1990;212:249-256.

193. Starzl TE, Todo S, Fung J, Demetris AJ, Venkataramanan R, Jain A. FK 506 for human liver, kidney and pancreas transplantation. Lancet $1989 ; 2: 1000-1004$.

194. Kino T, Hatanaka H, Miyata S, et al. FK506, a novel immunosuppressant isolated from Streptomyces: immunosuppressive effect of FK-506 in vitro. Jpn I Antibiot 1987;40:1256-1265.

195. Ochiai T, Nakajima K, Nagata $M$, et al. Effect of a new immunosuppressive agent, FK506, on heterotopic allotransplantation in the rat. Transplant Proc 1987;19:1284-1286.

196. Murase N, Todo S, Lee P-H, et al. Heterotopic heart transplantation in the rat under FK-506 alone or with cyclosporine. Transplant Proc 1987;19:71-75.

197. Lee P, Murase N, Todo S, Makowka L, Starzl TE. The immunosuppressive effects of FR 900506 in rats receiving heterotopic cardiac allografts. Surg Res Commun 1987;1:325-331.

198. Todo S, Podesta L, ChapChap P, et al. Orthotopic liver transplantation in dogs receiving FK-506. Transplant Proc 1987;19:64 67.

199. Todo S, Ueda Y, Demetris JA, et al. Immunosuppression of canine, monkey, and baboon allografts by FK 506 with special reference to synergism with other drugs, and to tolerance induction. Surgery $1988 ; 104: 239-249$.

200. Todo S, Demetris A, Ueda Y, et al. Renal transplantation in baboons under FK 506. Surgery 1989;106:444-451.

201. Fung $\pi$, Todo S, Jain A, et al. Conversion of liver allograft recipients with cyclosporine related complications from cyclosporine to FK 506. Transplant Proc 1990;22:6-12.

202. Armitage IM, Kormos RL, Griffith BP, et al. The clinical trial of FK 506 as primary and rescue immunosuppression in cardiac transplantation. Transplant Proc 1991;23:1149-1152.

203. Todo S, Fung J, Starzl TE, et al. Liver, kidney, and thoracic organ transplantation under FK 506. Ann Surg 1990;212:295-305.

204. Starzl TE, Fung J, Jordan $M$, et al. Kidney transplantation under FK 506. JAMA 1990;264:63-67.

205. Starzl TE, Donner A, Eliasziw $M$, et al. Randomized trialomania? The multicenter liver transplant trials. Lancet 1995;346: 1346-1350.

206. Fung $\pi$, Todo S, Tzakis A, et al. Conversion of liver allograft recipients from cyclosporine to FK506-based immunosuppression: benefits and pitfalls. Transplant Proc 1991:23:14 21.

207. Fung JJ, Todo S, Jain A, Demetris AJ, McMichael JP, Starzl TE. The Pittsburgh randomized trial of tacrolimus versus cyclosporine for liver transplantation. I Am Coll Surg 1996;183:117125.

208. The European FK 506 Multicentre Liver Study Group. Randomized trial comparing tacrolimus (FK 506) and cyclosporin in prevention of liver allograft rejection. Lancet 1994;344:423428.

209. The U.S. Multicenter FK 506 Liver Study Group. A comparison of tacrolimus (FK 506) and cyclosporine for immunosuppression in liver transplantation. N Engl J Med 1994;331:1110-1115. 
210. Starzl TE, Abu-Elmagd K, Tzakis A, Fung J, Porter KA, Todo S. Selected topics on FK 506: with special references to rescue of extrahepatic whole organ grafts, transplantation of "forbidden organs," side effects, mechanisms, and practical pharmacokinetics. Transplant Proc 1991;23:914-919.

211. Todo S, Tzakis AG, Abu-Elmagd K, et al. Intestinal transplantation in composite visceral grafts or alone. Ann Surg 1992;216:223234.

212. Todo S, Tzakis AG, Abu-Elmagd $\mathrm{K}$, et al. Cadaveric small bowel and small bowel-liver transplantation in humans. Transplantation (Baltimore) 1992;53:369-376.

213. Starzl TE, Brittain RS, Stonington OG, Coppinger RW, Waddell WR. Renal transplantation in identical twins. Arch Surg 1963; 865:600-607.

214. Owens TC, Prevedel AE, Swan H. Prolonged experimental occlusion of thoracic aorta during hypothermia. Arch Surg 1955;70:95-97.

215. Starzl TE. Experience in Renal Transplantation. Philadelphia: Saunders; 1964:68-71.

216. Marchioro TL, Huntley RT, Waddell WR, Starzl TE. Extracorporeal perfusion for obtaining postmortem homografts. Surgery $1963 ; 54: 900-911$.

217. Ackerman JR, Snell ME. Cadaveric renal transplantation. Br J Urol 1968;40:515-521.

218. Merkel FK, Jonasson O, Bergan J. Procurement of cadaver donor organs: evisceration technique. Transplant Proc 1972;4:585589.

219. Starzl TE, Hakala TR, Shaw BW Jr, et al. A flexible procedure for multiple cadaveric organ procurement. Surg Gynecol Obstet 1984;158:223-230.

220. Starzl TE, Miller C, Broznick B, Makowka L. An improved technique for multiple organ harvesting. Surg Gynecol Obstet 1987; 165:343-348.

221. Carrel A, Lindbergh CA. The Culture of Organs. New York: Hoeber; 1938.

222. Ackerman JR, Barnard CN. A report on the successful storage of kidneys. Br J Surg 1966;53:525-532.

223. Brettschneider L, Daloze PM, Huguet C, et al. The use of combined preservation techniques for extended storage of orthotopic liver homografts. Surg Gynecol Obstet 1968;126:263274.

224. Belzer FO, Ashby BS, Dunphy JE. 24-h and 72-h preservation of canine kidneys. Lancet 1967;2:536-538.

225. Collins GM, Bravo-Shugarman T, Terasaki PI. Kidney preservation for transportation: initial perfusion and $30 \mathrm{~h}$ ice storage. Lancet 1969;2:1219-1224.

226. Schalm SW. A Simple and Clinically Applicable Method for the Preservation of a Liver Homograft [thesis]. Holland: University of Leyden; 1968.

227. Benichou J, Halgrimson CG, Weil R II, Koep LJ, Starzl TE. Canine and human liver preservation for $6-19 \mathrm{~h}$ by cold infusion. Transplantation $1977 ; 24: 407-411$.

228. Wall WI, Calne RY, Herbertson BM, et al. Simple hypothermic preservation for transporting human livers long distances for transplantation. Transplantation 1977;23:210216.

229. Jamieson NV, Sundberg R, Lindell S, et al. Successful 24- to 30 $h$ preservation of the canine liver: a preliminary report. Transplant Proc 1988;29(suppl 1):945-947.

230. Kalayoglu M, Sollinger WH, Stratta RJ, et al. Extended preservation of the liver for clinical transplantation. Lancet 1988;1:617619 .

231. Todo S, Nery J, Yanaga K, Podesta L, Gordon RD, Starzl TE. Extended preservation of human liver grafts with UW solution. JAMA 1989;261:711-714.

232. Hoffman $B$, Sollinger $H$, Kalayoglu $M$, Belzer FO. Use of UW solution for kidney transplantation. Transplantation $1988 ; 46: 338-$ 339.
233. Wahlberg JA, Love R, Landegaard L, Southard $\mathrm{TH}$, Belzer FO. $72-h$ preservation of the canine pancreas. Transplantation 1987;43:5-8.

234. Ploeg RJ, Goossens D, McAnulty IF, Southard TH, Belzer FO. Successful 72-h cold storage of dog kidneys with UW solution. Transplantation 1988;46:191-196.

235. Ueda $Y$, Todo S, Imventarza $O$, et al. The UW solution for canine kidney preservation: its specific effect on renal hemo. dynamics and microvasculature. Transplantation 1989;48:913918.

236. Belzer FO, Southard JH. Principles of solid-organ preservation by cold storage. Transplantation 1988;45:673-676.

237. Todo S, Podesta L, Ueda $Y$, et al. A comparison of UW with other solutions for liver preservation in dogs. Clin Transplant 1989;3: 253-259.

238. Starzl TE, Nalesnik MA, Porter KA, et al. Reversibility of lymphomas and lymphoproliferative lesions developing under cyclosporin-steroid therapy. Lancet 1984;1:583-587.

239. Starzl TE. The mother lode of liver transplantation: with particular reference to our new journal. Liver Transplant Surg 1998;4:1-14.

240. Starzl TE, Marchioro TL, Rowlands DT Ir, et al. Immunosuppression after experimental and clinical homotransplantation of the liver. Ann Surg 1964;160:411-439.

241. Marchioro TL, Porter KA, Dickinson TC, Faris TD, Starzl TE. Physiologic requirements for auxiliary liver homotransplantation. Surg Gynecol Obstet 1965;121:17-31.

242. Starzl TE, Francavilla A, Halgrimson CG, et al. The origin, hormonal nature, and action of hepatotrophic substances in portal venous blood. Surg Gynecol Obstet 1973;137:179-199.

243. Starzl TE, Porter KA, Putnam CW. Intraportal insulin protects from the liver injury of portacaval shunt in dogs. Lancet 1975;2: 1241-1246.

244. Francavilla A, Hagiya M, Porter KA, Polimeno L, Ihara I, Starzl TE. Augmenter of liver regeneration (ALR): its place in the universe of hepatic growth factors. Hepatology 1994;20:747-757.

245. Starzl TE, Jones AF, Terblanche J, Usui S, Porter KA, Mazzoni G. Growth-stimulating factor in regenerating canine liver. Lancet 1979;1:127-130.

246. Hagiya M, Francavilla A, Polimeno L, et al. Cloning and sequence analysis of the rat augmenter of liver regeneration (ALR) gene: expression of biology active recombinant ALR and demonstration of tissue distribution. Proc Natl Acad Sci USA 1994;91:81428146.

247. Giorda R, Hagiya M, Seki T, et al. Analysis of the structure and expression of the ALR gene. Mol Med 1966;2:97-108.

248. Starzl TE, Demetris AI, Van Thiel DH. Medical progress: liver transplantation. N Engl J Med 1989;321(pt I):1014-1022.

249. Starzl TE, Bilheimer DW, Bahnson HT, et al. Heart-liver transplantation in a patient with familial hypercholesterolemia. Lancet $1984 ; 1: 1382-1383$.

250. Bilheimer DW, Goldstein Л, Grundy SC, Starzl TE, Brown MS. Liver transplantation provides low-density-lipoprotein receptors and lowers plasma cholesterol in a child with homozygous familial hypercholesterolemia. N Engl J Med 1984;311:16581664.

251. Starzl TE. The little drummer girls. In: The Puzzle People. Pittsburgh: University of Pittsburgh Press; 1992:318-333.

252. Snell GD. Methods for the study of histocompatibility genes. J Genet 1948;49:87-103.

253. Brent L. Immunogenetics: histocompatibility antigens-genetics, structure and function. In: A History of Transplantation Immunology. London: Academic Press; 1997:131-182.

254. Dausset J. Iso-leuco-anticorps. Acta Haematol 1958;20:156.

255. Van Rood J, Eernisses JG, van Leeuwen A. Leucocyte antibodies in sera of pregnant women. Nature 1958;181:1735.

256. Terasaki PI, McClelland JD. Microdroplet assay of human serum cytoxins. Nature 1964;204:998-1000. 
257. Starzl TE, Marchioro TL, Holmes JH, et al. Renal homografts in patients with major donor-recipient blood group incompatibilities [addendum]. Surgery 1964;55:195-200.

258. Starzl TE, Ishikawa M, Putnam CW, et al. Progress in and deterrents to orthotopic liver transplantation, with special reference to survival, resistance to hyperacute rejection, and biliary duct reconstruction. Transplant Proc 1974;6:129-139.

259. Rapaport FT, Dausset J, Legrand L, Barge A, Lawrence HS, Converse JM. Erythrocytes in human transplantation: effects of pretreatment with $A B O$ group-specific antigens. I Clin Invest $1968 ; 47: 2202-2216$.

260. Terasaki PI, Marchioro TL, Starzl TE. Sero-typing of human lymphocyte antigens: preliminary trials on long-term kidney homograft survivors. In: Histocompatibility Testing. Washington, DC: National Academy of Science Research Council; 1965:83-96.

261. Kissmeyer-Nielsen F, Olsen S, Peterson VP, Fieldborg O. Hyperacute rejection of kidney allografts associated with preexisting humoral antibodies against donor cells. Lancet 1966;2:662665.

262. Willimas GM, Hume DM, Hudson RP, Morris PI, Kano K, Milgrom F. "Hyperacute" renal-homograft rejection in man. N Engl J Med 1968;279:611-618.

263. Starzl TE, Lerner RA, Dixon FI, Groth CG, Brettschneider L, Terasaki PI. Shwartzman reaction after human renal transplantation. N Engl J Med 1968;278:642-648.

264. Patel R, Terasaki PI. Significance of the positive crossmatch test in kidney transplantation. N Engl I Med 1969;280:735739.

265. Simpson KM, Bunch DL, Amemiya $\mathrm{H}$, et al. Humoral antibodies and coagulation mechanisms in the accelerated or hyperacute rejection of renal homografts in sensitized canine recipients. Surgery $1970 ; 68: 77-85$.

266. Boehmig HI, Giles GR, Amemiya $H$, et al. Hyperacute rejection of renal homografts: with particular reference to coagulation changes, humoral antihodies, and formed blood elements. Transplant Proc 1971;3:1105-1117.

267. Starzl TE, Boehmig H), Amemiya $\mathrm{H}$, et al. Clotting changes, including disseminated intravascular coagulation, during rapid renal-homograft rejection. N Engl J Med 1970;283:383390.

268. Myburgh JA, Cohen I, Gecelther L, et al. Hyperacute rejection in human-kidney allografts Shwartzman or Arthus reaction? N Engl I Med 1969;281:131-134.

269. Cerilli I, Brasile L, Galouzis T, Lempert N, Clarke J. The vascular endothelial cell antigen system. Transplantation 1985;39:286289.

270. Brasile L, Zerbe T, Rabin B, Clarke J, Abrahms A, Cerilli T. Identification of the antibody to vascular endothelial cells in patients undergoing cardiac transplantation. Transplantation 1985;40:672675 .

271: Knechtle SJ, Halperin EC, Bollinger RR. Xenograft survival in two species combinations using total-lymphoid irradiation and cyclosporin. Transplantation 1987;43:173-175.

272. Gubematis G, Lauchart W, Jonker M, et al. Signs of hyperacute rejection of liver grafts of Rhesus monkeys after donor-specific presensitization. Transplant Proc 1987;19:1082-1083.

273. Merion RM, Colletti LM. Demonstration of hyperacute rejection (HAR) in outbred large animal model of liver transplantation (LTX). Transplantation 1990;49:861-868.

274. Takaya S, Bronsther O, Iwaki $Y$, et al. The adverse impact on liver transplantation of using positive cytotoxic crossmatch donors. Transplantation 1992;53:400-406.

275. Starzl TE, Demetris AI, Todo S, et al. Evidence for hyperacute rejection of human liver grafts: the case of the canary kidneys. Clin Transplant 1989;3:37-45.

276. Starzl TE. Tissue matching. In: The Puzzle People. Pittsburgh: University of Pittsburgh Press; 1992:118-124.
277. Brent L. Immunogenetics: histocompatibility antigens-struc ture and function. In: A History of Transplantation Immunology. London: Academic Press; 1997:153-159.

278. Starzl TE, Marchioro TL, Terasaki PI, et al. Chronic survival after human renal homotransplantations: lymphocyte-antigen matching, pathology and influence of thymectomy. Ann Surg $1965 ; 162: 749-787$

279. Terasaki PI, Vredevoe DL, Mickey MR, et al. Serotyping for homotransplantation: selection of kidney donors for thirty-two recipients. Ann N Y Acad Sci 1966;129:500-520.

280. Rapaport FT, Lawrence HS, Thomas L, Converse JM, Tillett WS Mulholland $\pi \mathrm{H}$. Cross-reactions to skin homografts in man. $\mathrm{J}$ Clin Invest 1962;41:2166-2172.

281. Dausset J, Rapaport FT. The Hu-1 system of human histocompatibility. In: Rapaport FT, Dausset J, eds. Human Transplantation. New York: Grune and Stratton; 1968: 369.

282. Rapaport FT, Dausset J. Behavior of HLA-compatible and incompatible skin allografts in human recipients preimmunized with pooled leukocyte extracts obtained from randomly selected donors. Transplantation 1983;36:592-594.

283. Starzl TE, Porter $\mathrm{KA}$, Andres $\mathrm{G}$, et al. Long-term survival after renal transplantation in humans: with special reference to histocompatibility matching, thymectomy, homograft glomerulonephritis, heterologous ALG, and recipient malignancy. Ann Surg 1970;172:437-472.

284. Mickey MR, Kreisler M, Albert ED, Tanaka N, Terasaki PI. Analysis of HL-A incompatibility in human renal transplants. Tissue Antigens 1971;1:57-67.

285. Starzl TE, Eliasziw M, Gjertson $M$, et al. HLA and cross reactive antigen group (CREG) matching for cadaver kidney allocation. Transplantation 1997;64:983-991.

286. Starzl TE, Demetris AJ, Murase N, Ricordi C, Trucco M. The enigma of graft acceptance. In: Shumway SI, Shumway NE, eds. Thoracic Transplantation. London: Blackwell Science; 1995:452470.

287. Starzl TE, Demetris AJ, Trucco $M$, et al. Systemic chimerism in human female recipients of male livers. Lancet 1992;340:876877.

288. Starzl TE, Demetris AJ, Trucco M, et al. Chimerism and donorspecific nonreactivity 27 to 29 years after kidney allotransplantation. Transplantation 1993;55:1272-1277.

289. Starzl TE, Demetris AJ, Trucco M, et al. Chimerism after liver transplantation for type $\Gamma \mathrm{V}$ glycogen storage disease and type I Gaucher's disease. N Engl J Med 1993;328:745-749.

290. Demetris AJ, Murase N, Starzl TE. Donor dendritic cells after liver and heart allotransplantation under short-term immunosuppression. Lancet 1992;339:1610.

291. Demetris AJ, Murase N, Fujisaki S, Fung II, Rao AS, Starzl TE. Hematolymphoid cell trafficking, microchimerism, and GVHD reactions after liver, bone marrow, and heart transplantation. Transplant Proc 1993;25:3337-3344.

292. Qian S, Demetris AJ, Murase N, Rao AS, Fung II, Starzl TE. Murine liver allograft transplantation: tolerance and donor cell chimerism. Hepatology 1994;19:916-924.

293. Murase N, Starzl TE, Tanabe M, et al. Variable chimerism, graft versus host disease, and tolerance after different kinds of cell and whole organ transplantation from Lewis to Brown-Norway rats. Transplantation 1995;60:158-171.

294. Michie D, Woodruff MFA, Zeiss IM. An investigation of immunological tolerance based on chimera analysis. Immunology $1961 ; 4: 413-424$.

295. Simonsen M. Graft versus host reactions: their natural history, and applicability as tools of research. Prog Allergy 1962;6:349467.

296. Bain B, Vas MR, Lowenstein L. The development of large immature mononuclear cells in mixed leukocyte cultures. Blood 1964;23:108-116. 
297. Bach F, Hirschhorn K. Lymphocyte interaction: a potential histocompatibility test in vitro. Science 1964;143:813-814.

298. Martinez C, Shapiro F, Good RA. Essential duration of parabiosis and development of tolerance to skin homografts in mice. Proc Soc Exp Biol Med 1960;104:256-259.

299. Ildstad ST, Sachs DH. Reconstitution with syngeneic plus allogeneic or xenogeneic bone marrow leads to specific acceptance of allografts or xenografts. Nature (Lond) 1984;307:168-170.

300. Thomas J, Carver M, Cunningham P, Park K, Gonder J, Thomas F. Promotion of incompatible allograft acceptance in rhesus monkeys given posttransplant antithymocyte globulin and donor bone marrow: in vivo parameters and immunohistologic evidence suggesting microchimerism. Transplantation (Baltimore) $1987 ; 43: 332-338$.

301. Przepiorka D, Thomas ED, Durham DM, Fisher L. Use of a probe to repeat sequence of the $Y$ chromosome for detection of host cells in peripheral blood of bone marrow transplant recipients. Am J Clin Pathol 1991;95:201-206.

302. Lawrence HS. Homograft sensitivity: an expression of the immunologic origins and consequences of individuality. Physiol Rev $1959 ; 39: 811-859$.

303. Medawar PB. The immunology of transplantation. In: The Harvey Lectures. Series 52. New York: Academic Press; 19561957:144-166.

304. Zinkernagel RM, Doherty PC. Restriction of in vitro $\mathrm{T}$ cellmediated cytotoxicity in lymphocytic choriomeningitis within a syngeneic or semi-allogeneic system. Nature 1974;248:701702.

305. Zinkernagel RM. Restriction by $\mathrm{H}-2$ gene complex of transfer of cell-mediated immunity to Listeria monocytogenes. Nature 1974;251:230-233.

306. Doherty PC, Zinkemagel RM. A biological role for the major histocompatibility antigens. Lancet 1975;1:1406-1409.
307. Zinkernagel RM, Doherty PC. The discovery of MHC restriction. Immunol Today 1997;18:14-17.

308. Zinkernagel RM. Immunology taught by viruses. Science 1996;271:173-178.

309. Zinkernagel RM, Ehl S, Aichele P, Oehen S, Kundig T, Hengartner $H$. Antigen localization regulates immune responses in a dose- and time-dependent fashion: a geographical view of immune reactivity. Immunol Rev 1997,156:199-209.

310. Starzl TE, Rao AS, Murase N, Fung J, Demetris AJ. Will xenotransplantation ever be feasible? J Am Coll Surg 1998;186:383387.

311. Sterzl J, Silverstein AM. Development aspects of immunity. Adv Immunol 1967;6:337-459.

312. Matzinger P. Tolerance, danger, and the extended family. Ann Rev Immunol 1994;12:991-1045.

313. Ridge JP, Fuchs EJ, Matzinger P. Neonatal tolerance revisited: turning on newborn $T$ cells with dendritic cells. Science 1996;271:1723-1726.

314. Starzl TE. Zinkernagel R. Antigen localization and migration in immunity and tolerance. N Engl J Med 1998;339:1905-1913.

315. Starzl TE, Zinkemagel R: Transplantation tolerance from a historical perspective. Nat Rev Immunol 2001;1:233-239.

316. Starzl TE. Organ transplantation: a practical triumph and epistemologic collapse. Proc Am Philos Soc 2003;147:226-245.

317. Starzl TE. The saga of liver replacement, with particular reference to the reciprocal influence of liver and kidney transplantation (1955-1967). J Am Coll Surg 2002;195:587-610.

318. Starzl TE, Murase N, Abu-Elmagd K, et al. Tolerogenic immunosuppression for organ transplantation. Lancet 2003;361:15021510.

319. Starzl TE, Lakkis FG. The unfinished legacy of liver transplantation: emphasis on immunology. Hepatology 2006;43(2 Suppl 1): S151-163. 